Pegem Eğitim ve Öğretim Dergisi, 11(1), 2021, 163-186

www.pegegog.net

\title{
Parents' Attributions and Perception Questionnaire: Turkish validity and reliability study
}

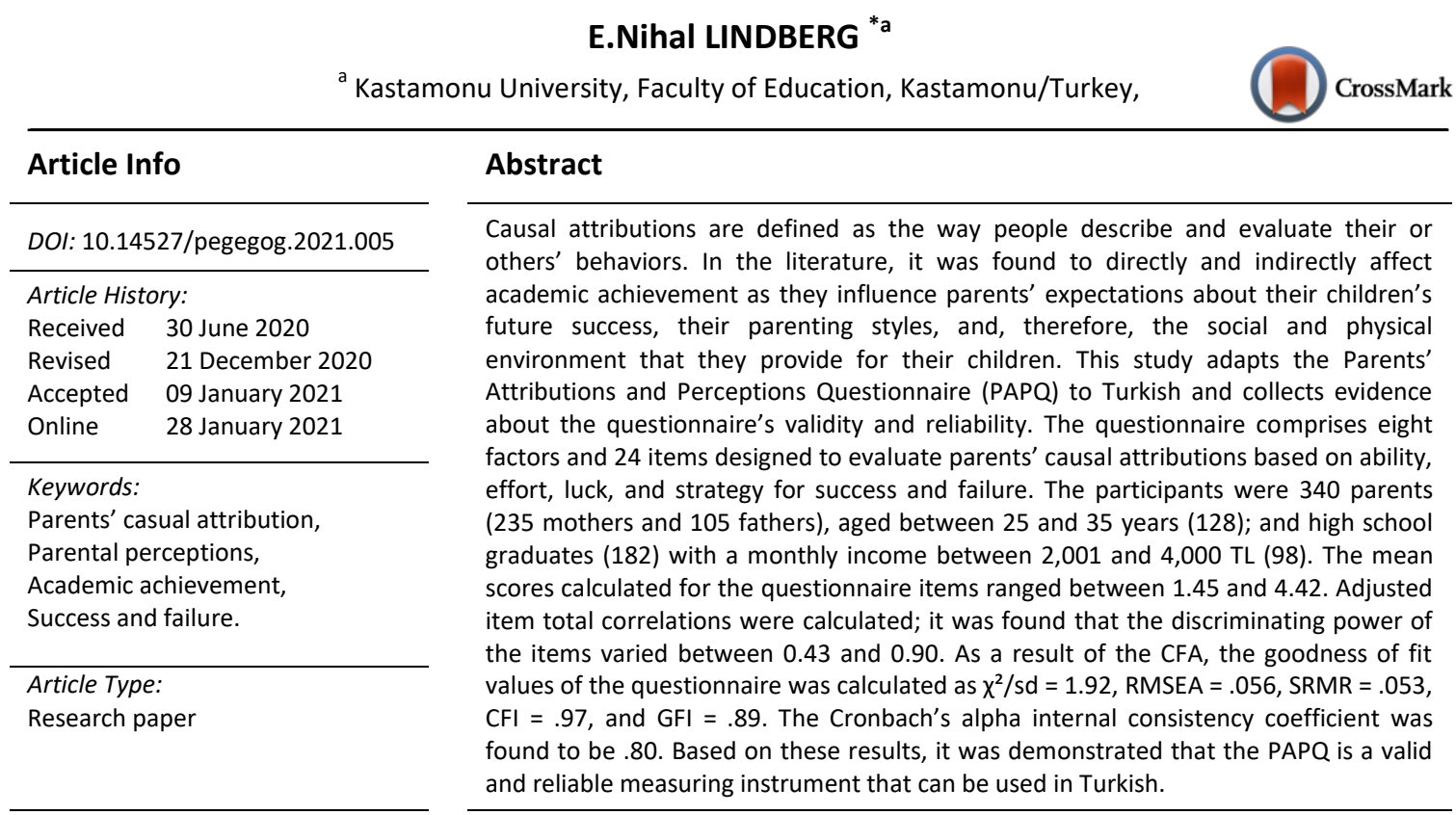

\section{Ebeveyn Başarıya Dönük Nedensel Yükleme Ölçeği (ENEYÖ): Türkçe geçerlilik ve güvenirlilik çalışması}

\begin{tabular}{|c|c|}
\hline Makale Bilgisi & Öz \\
\hline DOI: 10.14527/pegegog.2021.005 & $\begin{array}{l}\text { Nedensel yüklemeler, kişinin kendisinin ya da başkalarının davranışlarını açıklama ve } \\
\text { değerlendirme biçimini olarak tanımlanmaktadır. Alanyazında nedensel yüklemelerin, }\end{array}$ \\
\hline Makale Geçmişi: & ana babaların, çocuklarının gelecekteki başarısına yönelik beklentilerini, çocuk \\
\hline Geliş $\quad 30$ Haziran 2020 & yetiştirme stilleri ve dolayısıyla çocuklarına sundukları toplumsal ve fiziksel çevreyi de \\
\hline Düzeltme 21 Aralık 2020 & etkilediği için akademik başarı üzerinde doğrudan ve dolaylı etkileri olduğu \\
\hline Kabul $\quad 09$ Ocak 2021 & belirtilmektedir. Bu çalışmada, Ebeveyn Başarıya Dönük Nedensel Yükleme Ölçeği \\
\hline Çevrimiçi 28 Ocak 2021 & $\begin{array}{l}\text { (ENEYÖ)'nin Türkçeye uyarlamasının yapılıp, ölçeğin geçerlilik ve güvenirliliğine ilişkin } \\
\text { kanıtların elde edilmesi amaçlanmıştır. Ölçek; ana babaların hem başarı hem }\end{array}$ \\
\hline $\begin{array}{l}\text { Anahtar Kelimeler: } \\
\text { Ebeveyn nedensel yüklemeleri, } \\
\text { Ana baba algıları, } \\
\text { Akademik başarı, } \\
\text { Başarı ve başarısızık. }\end{array}$ & $\begin{array}{l}\text { başarısızlık için yetenek, çaba, şans ve strateji özellikleri temelinde yaptıkları nedensel } \\
\text { yüklemeleri değerlendirmeye dönük sekiz alt boyut ve } 24 \text { maddeden oluşmaktadır. } \\
\text { Araştırmanın katııımcı grubu, çoğunluğu; il merkezinde yaşayan, yaşları } 25-35 \text { yaş } \\
\text { aralığında değişen (128), lise mezunu (182), aylık geliri } 2001-4000 \text { TL arası değişen (98), } \\
235^{\prime} i \text { anne ve } 105^{\prime} \text { 'i baba olmak üzere toplam } 340 \text { ana babadan oluşmaktadır. } \\
\text { ENEYÖ'nün maddelerine ilişkin hesaplanan puanların ortalaması, } 1.45-4.42 \text { arasında }\end{array}$ \\
\hline $\begin{array}{l}\text { Makale Türü: } \\
\text { Özgün makale }\end{array}$ & $\begin{array}{l}\text { değişmektedir. Düzeltilmiş madde toplam korelasyonları hesaplanmış; madde } \\
\text { ayırtedicilik değerlerinin } 0.43 \text { ile } 0.90 \text { arasında değiştiği belirlenmiştir. DFA sonucu } \\
\text { ölçeğin uyum iyiliği değerleri } \chi^{2} / \mathrm{sd}=1.92 \text {, RMSEA=.056, SRMR=.053, CFI=.97, GFI=.89 } \\
\text { olarak hesaplanmıştır. Cronbach alfa iç tutarlık katsayısı } .80 \text { olarak bulunmuştur. Tüm } \\
\text { bu sonuçlar temelinde, Ebeveyn Başarıya Dönük Nedensel Yükleme Ölçeği'nin } \\
\text { Türkçede kullanılabilecek geçerli ve güvenilir bir öllçme aracı olduğu ortaya konmuştur. }\end{array}$ \\
\hline
\end{tabular}




\section{Introduction}

The effects of parents on their children's performance at school or, in particular, their academic achievement is now acknowledged by the literature. Moreover, parents' behaviors, opinions, and emotions regarding their children' school and academic success have short term effects (e.g. a school year) as well as long-term effects (e.g. academic motivation, school attendance). Considering Vygotsky's (1978) theory, the most important reason for this is the mediatory role of parents in the development and education of their children. Accordingly, in their direct and indirect interactions with their children, parents make use of their own personal values and beliefs, shaped by social, cultural, and historical characteristics of their communities. These values and beliefs, which provide the basis for parental behavior and opinions, are now conceptualized as parental cognition and regarded as the most important variable in the parenting process (Fan \& Chen, 2001; Jeynes, 2005, 2007; Lansford \& Bornstein, 2011; Miller, 1995). Miller (1995) states that there may be two possible reasons for this. The first reason is that parents ask why questions about almost everything related to their children. Why did they get a weak grade in math, why do they not study for the classes, why are they acting like this? With such questions, parents try to understand the behavior of their children and try to answer these questions within the context of their own cognitive framework. Therefore, it is important to understand this cognitive framework as it contributes to explanations of the factors that affect the education and development of children. Another reason is that the parental cognition directly or indirectly affects all behaviors and emotions of parents toward their children, and, consequently, the entire development of their children. The direct impact of parental cognition can be explained with parental behaviors such as providing private lessons, books, computers, and other facilities or participating in the education of their children to support their academic success. However, the indirect effects of cognitions appear to be more important as they relate to causal attributions that form the basis of these behaviors. Accordingly, the thoughts of parents about the reason why their children exhibit certain types of behavior affect all their behaviors that seek to support the education and development of their children (Enlund, Aunola, Tolvanen, Lerkkanen, \& Nurmi, 2017; Miller, 1995; Natale, Aunola, \& Nurmi, 2009; Räty, Vänskä, Kasanen, \& Kärkkäinen, 2002; Tõeväli \& Kikas, 2017).

\section{Causal Attributions for Success and Failure}

Causal attribution describes the way people explain and evaluate their or others' behaviors. For Weiner (Weiner, 2010), causal attributions for success and failure are related to how people explain the successes and failures of themselves or others. Weiner (Weiner, 2010) states that people's attributions related to success/failure can be discussed in three dimensions. The first of them is the locus of control. Accordingly, the first question individuals ask in case of success/failure is whether it can be attributed to an internal or external factor. For example, a mother may attribute the success of her child in any lesson to the hard work of the child (internal) and failure of the child in another lesson to the teacher's not paying enough attention to the child (external). The second dimension relates to the stability of the attribution about success/failure. Thus, a father may see the success of his child in a lesson as expected (stable) because of the aptitude of the child, whereas another father may explain his child's failure with the child's lack of interest in school or learning because he or she is in adolescence (unstable). The last factor Weiner (Weiner, 2010) mentions is the controllability of success or failure. Accordingly, a mother may believe that her child may be successful if he or she studies regularly (controllable) or her child may not be successful because he or she has the ability to graduate from secondary school at most (uncontrollable). In addition to these dimensions, it is emphasized that in case of failure, people explain the situation depending on four possible factors. Accordingly, ability as an immutable, uncontrollable, and internal feature; effort as a variable, controllable, and internal feature; teaching strategies/teacher adequacy as a changeable, uncontrollable, and external feature; and finally, luck as a changeable, uncontrollable, and external factor. Weiner (Weiner, 2010) argues that the parents' attributions for success affect their expectations and feelings about the future success of their children. Moreover, it is maintained that these expectations and emotions affect the social and physical environment that parents offer to their children as well as their parenting styles and, therefore, have a direct and indirect 
influence on children's academic achievement. In support of these views, it is indicated in the literature that the expectations and behaviors of parents about their children's education are the most important variable that influences academic achievement (Jeynes, 2005, 2007), and that there are positive significant correlations between these expectations and behaviors and the parents' attributions for success (Georgiou, 1999; Natale et al., 2009; Tõeväli \& Kikas, 2017)

Causal attributions of parents related to success and failure can vary depending on different factors. Literature shows that parents with a high level of education tend to attribute success to ability at a higher level compared with the parent with a lower level of education, and this is the case in Western communities more than in Asian ones (Enlund et al., 2017; Phillipson, 2006; Rytkönen, Aunola, \& Nurmi, 2005). Additionally, causal attributions can vary depending on the gender and age of the child. For example, Räty et al. (2002) demonstrated that the success of boys in the field of mathematics is explained more with ability and the success of girls in the same field more with effort, whereas the achievements of girls in the verbal field are explained more with ability and that of boys more with effort. In the same study, it was further shown that the previous performance levels of children influenced the attributions of parents for success/failure, and the success of the students who are generally successful in mathematics is attributed to ability, while the mathematical success of an average or mediocre student is explained with effort. This is supported by the works of Kinlaw, KurtzCostes, and Goldman-Fraser (2001) (2001) and Natale et al. (2009). In the studies, it is noted that success is attributed more to ability, and failure is explained more with effort. Miller (1995) and Phillipson (2006) suggest that it may not be emotionally easy for parents to attribute failure to lack of ability, and it is easier to deal with effort instead. Additionally, Enlund et al. (2017), Kinlaw et al.(2001), Miller (1995), Rytkönen et al. (2005), and Räty et al. (2002) indicate that there is generally a very small likelihood to attribute success or failure to task difficulty/teaching strategies and luck. Phillipson and Phillipson (2012) note that attributions for success and failure are evaluated in a continuity ranging from luck (hardest) to effort (easiest).

In the literature, there are also studies concerning the effects of parents' attributions on the behavior and cognition of children related to school and education. Aunola, Nurmi, Niemi, Lerkkanen, and Rasku-Puttonen (2002), Enlund et al. (2017), Miller (1995), and Natale et al. (2009) assert that parents' attributions for success/failure influence children's subsequent achievements, their motivation for success, and feelings of self-sufficiency for success. Accordingly, it has been determined that in cases where success is attributed to ability, students' success increased compared with the previous level, but in cases where success is attributed to effort, success and academic motivation decreased. One possible reason for this is that, as Weiner (2010) stressed, the positive attributions of parents strengthen children's belief in their own abilities, and this is an important variable that helps to increase academic achievement. However, it is believed this can also be explained by the relationship between parents' attributions for success and their expectations for the success of their children, as Phillipson (2006) stressed. In the study, it is noted that the parents who attribute academic achievement of their children to an external, controllable, or variable reason, rather than attributing it to ability, also have lower expectations regarding the future education and achievements of their children. Miller (1995) and Natale et al. (2009) noted that these low expectations relating to academic achievement are transmitted verbally and behaviorally to children through school and task-based interactions between parents and children in everyday life. Researchers argued that such interactions involving low expectations negatively affect children's sense of self regarding their abilities as well as the levels of their schooloriented motives. However, there are also studies suggesting that parents' attributions for success and failure affect the content and form of their interactions with their children. Rytkönen et al. (2005) have demonstrated that the parents who attribute the success of their children in school to ability tend to increase their support to, and participation in, their children's schoolwork, which, in turn, has a positive effect on academic achievement. Weiner (2010) argues that in cases where failure is attributed to a controllable external cause, such as the lack of effort, children experience guilt and remorse, and in cases where it is attributed to an uncontrollable internal reason such as ability, they feel shame and inferiority. As aforementioned, all these emotional states negatively affect children's school success. 


\section{Purpose and Significance of the Study}

There are studies in Turkish literature that emphasized the role of parents in the education of children and their influence on their academic achievement. In these studies, which support the international literature, a positive relationship between parents' support to, and participation in the education of their children, especially their home-based participation, and the academic achievement of their children has been shown (Anıl, 2009; Erdogan \& Demirkasımoglu, 2010; Ipek, 2011; Sabancl, 2009; Şad, 2012). However, in the studies aimed at parents' participation in particular, the findings that reveal the limited, and even lack of, participation by parents despite the fact that both parents and teachers and principals believe in the importance and necessity of participation require more detailed research into the cause. Although the literature refers to certain characteristics of parents, schools, and children that prevent participation (education level, socioeconomic level, employment status, lack of openness to cooperation, and negative attitude about participation) (Basaran \& Koc, 2001; Ceylan \& Akar, 2011; Erdogan \& Demirkasımoglu, 2010; Keceli-Kaysılı, 2002; Lindberg, 2013; Sabancı, 2009; Şad, 2012), no study aiming to determine the beliefs and values of a parent about their roles in the education of their children and especially their personal and cultural attributions for success has been found, except for two studies (Kaya \& Bacanlı, 2015; Lindberg, Yildirim, Elvan, Ozturk, Recepoglu, 2019; Tekin, 2016). Kaya and Bacanlı (2015) focused on the role and competence perceptions of parents related to their roles and competencies for participation in the education of their children. They found that parents' acknowledgment of the importance of their self-efficacy levels for supporting the education of their children and their own positive school experiences also increased their participation in the education of their children. Lindberg et al. (2019) designed a qualitative study based on interviews. The study focused on the expectations of parents regarding the educational future of their children. In the study, it was demonstrated that the expectation levels of the participants comprising mostly mothers regarding their children were shaped by the personal wishes of the participants rather than by the existing levels of success of their children. Another important finding from this study was that parents' expectations that their children would be successful in school stemmed from their beliefs in the abilities or efforts of their children for schoolwork.

In the Turkish literature, no measurement tool aimed at determining the causal attributions of parents for success and failure with a cultural basis has been found. In this respect, the aim of the present study is to adapt the Parents' Attributions and Perception Questionnaire (PAPQ), developed by Phillipson and Phillipson (2010), into Turkish culture and language. On the basis of the literature outlined above, it is believed that this study is important for two reasons. First, the scale adapted within the scope of the study will make it possible to determine the causal attributions of Turkish parents for the success and failure of their children, which have strong personal and socio-cultural foundations. Indeed, these causal attributions, as aforementioned, affect all academic and social relationships of parents with their children and, therefore, children's school performances, their motivation toward school, and, eventually, their academic achievements. Second, it is also believed that this study will contribute to the advanced level applied studies to be conducted using the adapted scale on the influence of parents on their children's school achievement as well as to the work aimed at developing these effects in a positive direction.

\section{Method}

\section{Study Group}

To control the possible effects of cultural and contextual factors in the data collection process of the research, a total of 340 parents living in different parts of Turkey were reached. Of the parents, 100 (29\%) lived in Marmara and Aegean regions, 110 (32.3\%) in the Central Anatolia region, 80 (23.5\%) in the Black Sea region, and 50 (14.7\%) in the Eastern Anatolia region. Additionally, 48 (14.1\%) lived in metropolitan areas, 225 (66.2\%) in provincial centers, and 67 (19.8\%) in districts and smaller settlements. 
Of the participants, 235 were mothers (69\%) and 105 (30.9\%) were fathers; $128(37.7 \%)$ were aged between 20 and 35 years, 102 (30\%) between 36 and 40 years, and 110 (32.4\%) were above 40 . Regarding their education levels, 83 parents (24.4\%) were primary and secondary school graduates, 75 (22.1\%) were high school graduates, and 182 were (53.5\%) university graduates. Concerning the level of monthly income of the participants, 41 (12.1\%) earned TL 2,000 and below per month, 98 (28.8\%) between TL 2,001 and 4,000, 79 (22.2\%) between TL 4,001 and 6,000, 59 (17.4\%) between TL 6,001 and 8,000 TL, and 63 earned (18.5\%) TL 8,001 and above. Of the participants, 178 (52.4\%) had children attending primary school, 100 (29.4\%) secondary school, and 62 (18.2\%) high school.

\section{Data Collection Tools}

PAPQ, developed by Phillipson and Phillipson (2010) to measure the attributions of parents for the success and failure of their children in school-related activities, is a 24-item scale. The items in PAPQ contain statements about attributions for success and failure with factors of ability, effort, strategy, and luck. Accordingly, the factors are indicated as Success-Luck, Success-Ability, Success-Effort, SuccessStrategy, Failure-Luck, Failure-Ability, Failure-Effort, and Failure-Strategy. For example, the item, "When my child does well in exams, it is likely because he or she is just lucky," relates to the factor of Success-Luck, whereas the item, "When my child does poorly in the school math test, it is likely because he or she is not good at it," falls under the factor of Failure-Ability. Parents are asked to rate their agreement with each item on a 5-point Likert-type scale ranging from 1 (I strongly disagree) to 5 (I strongly agree). In accordance with the aforementioned aim for the development of the scale and its basic theoretical structure, a separate score is obtained for each factor. Thus, the highest score of each factor is 15 and the lowest score is 3 . The higher scores, for example, related to the factor of SuccessLuck are interpreted as the parents attributing success of their children more to luck.

Confirmatory factor analysis (CFA) was used to determine the conformity of the eight-factor structure of the original scale to the theoretical structure. It was reported that as a result of the analysis, each factor had three items and R2 values ranging from medium to wide range, and the eight-factor structure of the scale was confirmed based on regression coefficients of the items of each factor (Phillipson \& Phillipson, 2010). In the analysis concerning the fit of the CFA results obtained with the data, the ratio of $\chi 2$ to degrees of freedom $(\chi 2 / \mathrm{sd})$ was calculated as $1.56, \mathrm{GFI}=.90, \mathrm{CFI}=.94$, and RMSEA $=.05$. Additionally, the Cronbach's alpha, calculated for the entire 24-item scale, was .78. The Rasch analysis was used to obtain the averages that would enable nonlinear raw scores to be converted into linear ones in the form of standardized residual values. These residual values for the items obtained through the Rasch analysis contributed to increasing the chances of each item being loaded to the appropriate factor in the CFA. Moreover, the Rasch analysis based on the rating scale model was also used to determine whether the rating scale used on the questionnaire was functioning properly. As a result of the analysis, both in-fit and out-fit statistics were determined to be .99. In-fit and out-fit tvalues were also calculated as .00; this value was considered to be another result of the data-model fit. The reliability coefficient for the surface of the item was determined to be .99; this value was interpreted as indicating that the difficulty levels of the items differed from each other. The person ability estimate mean was found as -.21 , which meant that 215 participants in the sample found the items as relatively easy. In a sense, this revealed that the parents could be trusted to be capable of revealing their attributions about their children. For person fit measures, the in-fit mean square was 1.00, and the out-fit mean square was .99. In this measurement, the in-fit and out-fit t-value was -.30; this result was considered a sign of acceptable fit because of the person separation reliability of .75 (Phillipson \& Phillipson, 2010).

\section{Data Collection}

The participants were contacted directly by the researcher or through the school counselor or classroom or branch teachers known to the researchers and faculty members at the education faculties in the respective regions or cities. Prior to the data collection process, the teachers who would act as mediators for contacting the parents during the data collection process were interviewed, and they 
were informed about the purpose of the research, and how the data would be used. After they were informed, the link for the online form containing questions for demographic information about the participants as well as the item of the data collection tool were sent to the teachers. The online form primarily gave information about the purpose of the study, and how and where the data would be used, and mentioned the measures for ensuring the reliability of personal information. Thus, it was stressed that there was no question in the form that would indicate the identity of the respondent, and as the answers were filled out and sent online, it was impossible to link the respondent to the answers. It was further noted that participation in the study was voluntary; however, filling out and submitting the online form would mean being informed about the purpose and content of the study and agreeing to the researcher using the data.

\section{Data Analysis}

In this study, before performing CFA, assumptions were evaluated to determine whether the data set is suitable for the relevant analysis. Kline (2005) states that the sample size must be at least 200 for CFA to be applied. In this study, a sample group of 340 people was obtained. The second assumption specified for CFA is related to missing values. The data set was reviewed for the missing values, and it was determined that there was no missing value. The Mahalanobis distances for multivariate extreme values were examined. Accordingly, the chi-square values of the observations for 44 people were determined to be greater than .01, and the measurements for these people were removed from the data set. Then, it was checked whether the data showed multivariate normal distribution. Relative multivariate kurtosis (RMK) was evaluated for multivariate normality. Thus, the RMK value was calculated as 1.152. Although no standard cutting point was specified for this index (Jöreskog \& Sörbom, 1993), Pellegrini and Scandura, 2005) stated that a value less than 3 is an acceptable level for multivariate normality. The scattering diagram was examined for linearity, and it was observed that the data did not deviate excessively from linearity. Finally, before performing CFA, multiple co-linearity between the variables was also examined. It was found that the VIF value for the variables was significantly lower than 10 , and it was concluded that there was no multiple co-linearity for the data at hand.

\section{Findings}

\section{Translation Process and Content Validity of PAPQ}

In the process of adapting the scale, the adaptation steps specified by Hambleton and Patsula (1998) were followed. Accordingly, following the e-mail correspondence with the researchers who originally developed the scale, it was determined that the structural features of the scale were appropriate for the culture and language to which it would be adapted, and the permission was obtained from the researchers to adapt the scale to Turkish. After this stage, the scale was translated from English to Turkish by three experts who had a PhD degree in educational psychology and who were proficient in both languages. The first translations were examined individually in a meeting attended by all the experts who made the translations. In this meeting, the differences related to the translation of each item were discussed, and proposals for eliminating these differences were taken into consideration to give the scale its initial form. In this process, one expert with a PhD degree in Curricula and Teaching and another expert with a PhD degree in Measurement and Evaluation in Education were consulted for the statements designed to determine the parent's attributions for success in spelling English words in item 15 (When my child comes in last in the school spelling test, it is likely because he or she is just unlucky) and item 18 (When my child does poorly in the school spelling test, it is likely because he or she is not good at it), in line with the recommendations of the experts in the translation group. In accordance with the recommendations of the experts from the specified fields, it was decided that it was appropriate to use the math test instead of the spelling test in the Turkish form. Thus, the process of translation into Turkish was completed by preserving 24 items of the scale. 


\section{Descriptive Statistics}

After the completion of the translation process, the scale was applied to a sample group of 340 people. However, in the preliminary review process for determining the suitability of the data set for CFA, as noted above, it was decided in the analyses related to extreme values that the data for 44 people should be removed from the data set. Thus, the analysis was carried out with 296 people. The descriptive statistics on the data set are given in Table 1.

Table 1.

Descriptive Statistics Calculated for Items of PAPQ.

\begin{tabular}{|c|c|c|c|c|c|c|c|}
\hline & $\overline{\mathbf{X}}$ & Mod & Median & SD & Min. & Max. & $\begin{array}{l}\text { Item Total } \\
\text { Corelation }\end{array}$ \\
\hline \multicolumn{8}{|c|}{ 1.Factor - Success - Luck } \\
\hline M1 & 1.70 & 1.00 & 1.00 & 1.09 & 1 & 5 & .61 \\
\hline M2 & 1.47 & 1.00 & 1.00 & 0.78 & 1 & 5 & .79 \\
\hline M3 & 1.45 & 1.00 & 1.00 & 0.80 & 1 & 5 & .77 \\
\hline \multicolumn{8}{|c|}{ 2. Factor - Success - Ability } \\
\hline M4 & 3.16 & 4.00 & 3.00 & 1.29 & 1 & 5 & .66 \\
\hline M5 & 3.45 & 4.00 & 4.00 & 1.23 & 1 & 5 & .84 \\
\hline M6 & 3.54 & 4.00 & 4.00 & 1.23 & 1 & 5 & .81 \\
\hline \multicolumn{8}{|c|}{ 3. Factor - Success - Effort } \\
\hline M7 & 4.27 & 4.00 & 5.00 & 0.93 & 1 & 5 & .79 \\
\hline M8 & 4.35 & 5.00 & 5.00 & 0.86 & 1 & 5 & .84 \\
\hline M9 & 4.09 & 4.00 & 4.00 & 0.96 & 1 & 5 & .69 \\
\hline \multicolumn{8}{|c|}{ 4. Factor - Success - Strategy } \\
\hline M10 & 4.42 & 5.00 & 5.00 & 0.81 & 1 & 5 & .78 \\
\hline M11 & 4.31 & 5.00 & 5.00 & 0.88 & 1 & 5 & .87 \\
\hline M12 & 4.27 & 5.00 & 4.00 & 0.87 & 1 & 5 & .80 \\
\hline \multicolumn{8}{|c|}{ 5.Factor - Failure - Luck } \\
\hline M13 & 1.58 & 1.00 & 1.00 & 0.88 & 1 & 5 & .80 \\
\hline M14 & 1.54 & 1.00 & 1.00 & 0.90 & 1 & 5 & .90 \\
\hline. $\mathrm{M} 15$ & 1.61 & 1.00 & 1.00 & 1.01 & 1 & 5 & .83 \\
\hline \multicolumn{8}{|c|}{ 6. Factor - Failure - Ability } \\
\hline M16 & 3.04 & 4.00 & 3.00 & 1.29 & 1 & 5 & .46 \\
\hline M17 & 2.65 & 2.00 & 2.00 & 1.28 & 1 & 5 & .43 \\
\hline M18 & 3.30 & 4.00 & 4.00 & 1.28 & 1 & 5 & .52 \\
\hline \multicolumn{8}{|c|}{ 7. Factor - Failure - Effort } \\
\hline M19 & 4.06 & 4.00 & 4.00 & 0.95 & 1 & 5 & .72 \\
\hline M20 & 3.99 & 4.00 & 4.00 & 0.95 & 1 & 5 & .78 \\
\hline M21 & 4.12 & 4.00 & 4.00 & 0.91 & 1 & 5 & .84 \\
\hline \multicolumn{8}{|c|}{ 8. Factor - Failure - Strategy } \\
\hline M22 & 3.67 & 4.00 & 4.00 & 1.12 & 1 & 5 & .61 \\
\hline M23 & 3.93 & 4.00 & 4.00 & 0.97 & 1 & 5 & .77 \\
\hline M24 & 3.88 & 4.00 & 4.00 & 1.02 & 1 & 5 & .74 \\
\hline
\end{tabular}

As a result of the analysis carried out, the mean scores calculated for each item of PAPQ varied between 1.45 and 4.42, as shown in Table 1. Item total correlations were calculated to determine the distinctiveness of each item in the scale, and it was found that the distinctiveness values varied between 0.43 and 0.90 . It is stated that the values greater than .30 for the corrected item total correlation are within the acceptable limits (Büyüköztürk, 2011). Based on the results obtained in this study, it was understood that all scale items had high distinctiveness power based on the relevant factor. 


\section{Validity and Reliability of PAPQ}

The path diagram for CFA, drawn for examining the data fit of the model for the eight-factor structure of the 24-item Turkish form of the original scale, is given in Figure 1.

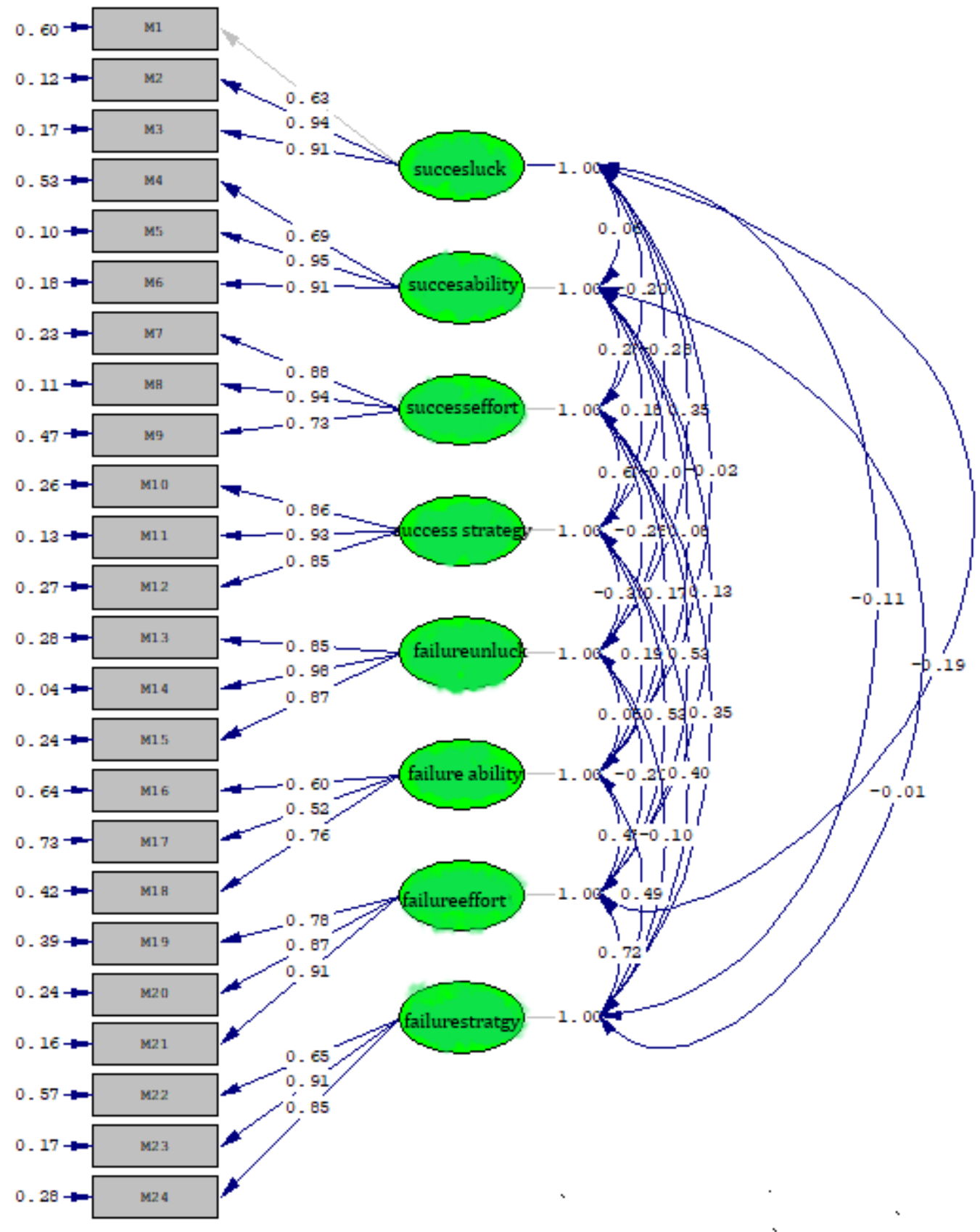

Figure 1. An eight-factor Parents' Attributions and Perceptions Questionnaire model showing the parental attributions of effort, ability, strategy, and luck on their children's success and failures at school.

As shown in Figure 1, as a result of CFA wherein the construct of the scale, comprising eight factors and 24 items, it was determined that the item factor loading values ( $\lambda s$ ) ranged from .52 to .95 . It was found that the t-values obtained as a result of the analysis were significant at the level of .05 , and the 
error variances of the items varied between .04 and .73 . Standardized beta coefficients were in the range of .52 to .98 . Based on these results, it was decided that none of the scale items needed to be removed. The statistics on the data fit of the CFA results obtained from PAPQ are given in Table 2.

Table 2.

Confirmatory Factor Analysis Results

\begin{tabular}{rrrrrrrr}
\hline$\chi 2$ & sd & $\chi 2 /$ sd & RMSEA & SRMR & CFI & GFI & $\begin{array}{r}\text { Cronbach } \\
\text { Alpha }\end{array}$ \\
\hline 432.11 & 224 & 1.92 & .056 & .053 & .97 & .89 & .80 \\
\hline
\end{tabular}

As shown in Table 2, all values for goodness of fit indices, mainly $\chi 2 / s d$, were within the acceptable intervals. Thus, it was concluded that the scale items were a good representative of the construct aimed at measuring the attributions of parents, and because of the fit of items with the data, the measurements made using PAPQ had construct validity. These results were also consistent with the results of the study by Phillipson and Phillipson (2010) for developing the original scale. In the study for developing the original scale, the $\chi 2$ /sd ratio was found as $1.56, \mathrm{RMSEA}$ as $0.05, \mathrm{CFI}$ as 0.94 , and GFI as 0.90 .

The interdimensional correlations in PAPQ are given in Table 3.

Table 3.

Pearson Correlation Coefficients between Factors of PAPQ.

\begin{tabular}{|c|c|c|c|c|c|c|c|c|c|}
\hline & & $\begin{array}{l}\text { Suc. } \\
\text { Luck }\end{array}$ & $\begin{array}{l}\text { Suc. } \\
\text { Ability }\end{array}$ & $\begin{array}{l}\text { Suc. } \\
\text { Effort }\end{array}$ & $\begin{array}{l}\text { Suc. } \\
\text { Strategy }\end{array}$ & $\begin{array}{l}\text { Fail. } \\
\text { Luck }\end{array}$ & $\begin{array}{l}\text { Fail. } \\
\text { Ability }\end{array}$ & $\begin{array}{l}\text { Fail. } \\
\text { Effort }\end{array}$ & $\begin{array}{l}\text { Fail. } \\
\text { Strategy }\end{array}$ \\
\hline \multirow[t]{2}{*}{$\begin{array}{l}\text { Succes } \\
\text { Luck }\end{array}$} & $\begin{array}{l}\text { Pearson } \\
\text { Correl. }\end{array}$ & 1 & .11 & $-.14^{*}$ & $-.22^{* *}$ & $.30^{* *}$ & -.004 & $-.13^{*}$ & -.05 \\
\hline & $p$ & & .05 & .01 & .000 & .000 & .94 & .01 & .31 \\
\hline \multirow[t]{2}{*}{$\begin{array}{l}\text { Succes } \\
\text { Ability }\end{array}$} & $\begin{array}{l}\text { Pearson } \\
\text { Correl. }\end{array}$ & & 1 & $.31^{* *}$ & $.18^{* *}$ & .03 & .11 & $.13^{*}$ & -.01 \\
\hline & $p$ & & & .000 & .001 & .52 & .05 & .02 & .85 \\
\hline \multirow[t]{2}{*}{$\begin{array}{l}\text { Succes } \\
\text { Effort }\end{array}$} & $\begin{array}{l}\text { Pearson } \\
\text { Correl. }\end{array}$ & & & 1 & $.57^{* *}$ & $-.23^{* *}$ & $.11^{*}$ & $.47^{* *}$ & $.31^{* *}$ \\
\hline & $p$ & & & & .000 & .000 & .04 & .000 & .000 \\
\hline $\begin{array}{l}\text { Succes } \\
\text { Strate }\end{array}$ & $\begin{array}{l}\text { Pearson } \\
\text { Correl. }\end{array}$ & & & & 1 & $-.35^{* *}$ & $.11^{*}$ & $.49^{* *}$ & $.36^{* *}$ \\
\hline gy & $p$ & & & & & .000 & .040 & .000 & .000 \\
\hline \multirow[t]{2}{*}{ e Luck } & $\begin{array}{l}\text { Pearson } \\
\text { Correl. }\end{array}$ & & & & & 1 & .07 & $-.18^{* *}$ & -.09 \\
\hline & $p$ & & & & & & .197 & .002 & .104 \\
\hline $\begin{array}{l}\text { Failur } \\
\mathrm{e}\end{array}$ & $\begin{array}{l}\text { Pearson } \\
\text { Correl. }\end{array}$ & & & & & & 1 & $.34^{* *}$ & $.35^{* *}$ \\
\hline Ability & $p$ & & & & & & & .000 & .000 \\
\hline $\begin{array}{l}\text { Failur } \\
\mathrm{e}\end{array}$ & $\begin{array}{l}\text { Pearson } \\
\text { Correl. }\end{array}$ & & & & & & & 1 & $.63^{* *}$ \\
\hline Effort & $p$ & & & & & & & & .000 \\
\hline
\end{tabular}

Analysis related to Pearson correlation coefficients shows that there were low and moderate and negative and positive relations between the factors. However, there was no significant correlation between some factors. Thus, no significant correlation was found between the Success-Luck factor and the Failure-Ability factor $(-.004, p>0.05)$ and the Failure-Strategy factor $(-.05, p>0.01)$, between the 
Success-Ability factor and the Failure-Luck factor $(.03, p>05)$ and the Failure-Strategy factor $(-.01, p>$ $05)$, and between the Failure-Luck factor and the Failure-Ability factor (.07, p > .05) and the FailureStrategy factor $(-.09, p>.05)$. Additionally, it is believed that the fact that the correlations obtained were not too high can be considered as an indication that there was no problem of multiple co-linearity between scale factors (Dereli-Iman, 2013).

In this study, the Cronbach's alpha internal consistency coefficient of the scale was determined as .80; Phillipson and Phillipson (2010) reported this coefficient as .78.

\section{Discussion and Conclusion}

The aim of this study was to adapt PAPQ, developed by Phillipson and Phillipson (2010), to determine parents' attribution for the success and failure of their children to Turkish. In line with the theoretical structure, the scale has eight factors under the overall dimensions of success and failure: Success-Ability, Success-Effort, Success-Strategy, Success-Luck, Failure-Ability, Failure-Effort, FailureStrategy, and Failure-Luck.

The results of fit indices obtained through CFA to determine whether the eight-factor structure of the original scale could be verified in Turkish culture support the model-data fit. As a result of the analysis, it was found that $\chi 2 / \mathrm{sd}=1.92, \mathrm{RMSEA}=.05, \mathrm{SRMR}=.05, \mathrm{CFI}=.97$, and $\mathrm{GFI}=.89$. In the literature, it is noted that the $\chi 2 / s d$ ratio less than or equal to 2 and 3 , the RMSEA value in the range of 0.06 to 0.08 , the SRMR value less than or equal to 0.08 , the CFI value of 0.90 and above, and the GFI value of 0.85 and above can be considered acceptable lower limits for the fit of the model with actual data (Tabachnick \& Fidell, 2007). The results obtained in this study support good and even perfect fit between the model and the data, in parallel to the results obtained from the original scale.

The Cronbach's alpha coefficient of the original scale was reported as .78. In this study, the Cronbach's alpha coefficient of the scale was determined as .80. In the literature for the assessment of reliability, it is reported that the closeness of the Cronbach's alpha coefficient to 1 is important, and the values closer to 1 indicate strong evidence of the reliability of the scale. In contrast, the Cronbach's alpha coefficient below .70 or above .90 signifies a problem for the reliability of the scale (Şencan, 2005). The value obtained in this study is within the acceptable limits.

As aforementioned, this adaptation study aimed to determine whether the theory-based model (parents' attributions for success and failure) could be verified. In this context, CFA was performed and the eight-factor structure of the scale in accordance with the construct defined at the original scale was validated; correlations were found between some factors/dimensions, or other factors were found to be unrelated. The correlation between the factors provides important information on the discrimination of the factors. Too high correlation estimation between the factors ( 0.85 and above) threatens the discriminant validity (Kline, 2005). Accordingly, the low and moderate levels of correlations that are significant between the factors in the study show that the relevant factor measures the attributions of parents for success and failure separately (Çokluk, Şekercioğlu, \& Büyüköztürk, 2018). However, in the present study, no significant correlation was found between the Success-Luck factor and the FailureAbility factor and the Failure-Strategy factor, between the Success-Ability factor and the Failure-Luck factor and the Failure-Strategy factor, and between the Failure-Luck factor and the Failure-Ability factor and the Failure-Strategy factor. However, this is supported by the initial measurement model. Additionally, Phillipson and Phillipson (2010) noted that each factor of the scale could be treated separately, and no a single total score from the scale would be calculated. In the present study, the results of CFA also prove that the model-data fit has been achieved, and the predicted relationships between the variables and the factors as well as among factors are verified. The basic model on which the scale is based (Weiner, 2010) and the literature on this topic (Lansford \& Bornstein, 2011; Miller, 1995; Phillipson \& Phillipson, 2010) show that success or failure in the academic field can be attributed to four different situations. Thus, the cause of success or failure in the academic field can be attributed to luck, effort, ability, or strategy. Additionally, in the literature, it is noted that parents attribute their 
children's success and failure mostly to ability and effort (Enlund et al., 2017; Kinlaw et al., 2001; Miller, 1995; Räty, Leinonen, et al., 2002; Rytkönen et al., 2005). In the studies, it is demonstrated that both success and failure are unlikely to be attributed to ability or strategy. The possible reason for this result may be parents' placing greater emphasis on effort and strategy and lesser emphasis on luck in their communication with their children on the basis of academic success, as Phillipson and Phillipson (2010) noted. This is because it is easier to explain success with reference to a feature that can be more easily exemplified in everyday life, such as effort and strategy, instead of an external and uncontrollable feature that is more difficult to measure and exemplify, such as luck. Moreover, the results of the Rasch analysis conducted in the process of developing the original scale demonstrated that the most difficult items for parents to answer were those in which success and failure should be attributed to luck and failure to strategy and effort. In the analysis, the easiest items to answer were found to be the ones that attribute success and failure to strategy and effort. Accordingly, the results obtained on the interdimensional relationship pattern in this scale adaptation study support the basic theoretical model and the literature as well as the results obtained during the development of the original scale.

In conclusion, it can be said that the Turkish form of PAPQ is a valid and reliable measuring tool that can be used to measure the attributions of parents related to their children's academic success and failure. Using this scale, it may be possible to describe success-failure attributions that affect the participation of parents in the education of their children and the support or guidance they provide for their children, which are important at an individual and socio-cultural level. Such descriptions will contribute to the improvement of the roles of parents, school managers, and teachers for participation in the development and education of children.

\section{Acknowledgments}

This study was produced from an international research project supported by TUBITAK 2219 International Postdoctoral Research Fellowship Program and carried out by the researcher between 2019-2020 
Turkish Version

\section{Giriş}

Ana babaların, çocuklarının okulda gösterdiği performans ya da özel olarak akademik başarıları üzerindeki etkileri bugün artık alanyazın tarafından tartışmasız kabul edilen bir gerçekliktir. Vygotsky'nin (1978) kuramı temelinde düşünüldüğünde, bu gerçekliğin en önemli nedeni, ana babanın, çocuğun gelişimi ve eğitimindeki aracılı rolüdür. Buna göre ana babalar, çocukları ile kurdukları tüm doğrudan ve dolaylı etkileşimlerde; bulundukları toplumun kültürel, toplumsal ve tarihsel özellikleri temelinde biçimlenen kendi kişisel değer ve inançlarını kullanmaktadırlar. Ana baba davranışlarına temel sağlayan bu değer ve inançlar, günümüzde ana babalık bilişleri (parental cognition) olarak kavramsallaştırılmakta ve ana babalık sürecinin en önemli etmeni ve bu sürecin merkezinde yer alan temel değişken olarak ele alınmaktadır (Fan \& Chen, 2001; Jeynes, 2005, 2007; Lansford \& Bornstein, 2011; Miller, 1995). Miller (1995), bunun olası iki nedeni olabileceğini belirtmektedir. Bunlardan ilki, ana babaların çocukları ile ilgili hemen hemen her konuda neden soruları soruyor olmalarıdır. Sözgelimi neden matematik dersinden zayıf not aldı, neden derslerine çalışmıyor, neden böyle davranıyor soruları yoluyla ana babalar, çocuğun davranışlarını anlamaya çalışmakta ve bunu çoğunlukla kendi bilişsel çerçeveleri içerisinde yanıtlamaya çalışmaktadırlar. Dolayısıyla bu bilişsel çerçevenin anlaşılması, çocuğun eğitimi ve gelişimini etkileyen etmenlere dönük açıklamalara katkı sağlıyor olması nedeniyle önemlidir. Bir diğer neden, ana baba bilişlerinin, onların çocuklarına yönelik tüm davranışlarını, duygularını ve dolayısıyla çocuklarının tüm gelişimini doğrudan ya da dolaylı olarak etkiliyor olmasıdır. Ana baba bilişlerinin doğrudan etkisi, ana babaların çocuklarının akademik başarısını desteklemeye dönük özel ders, kitap, bilgisayar gibi olanaklar ya da onun eğitimine katılım gösterme gibi davranışlarla açıklanabilir. Ancak bilişlerin dolaylı etkileri, belirtilen bu davranışların temelini oluşturan nedensel yüklemelerle ile ilgili olması nedeniyle daha önemli görünmektedir. Buna göre, ana babanın çocuğun belirli tür davranışları göstermesinin nedenine yönelik düşünceleri, onların çocuklarının eğitimini ve gelişimini desteklemeye yönelik tüm davranışlarını etkilemektedir (Enlund, Aunola, Tolvanen, Lerkkanen, \& Nurmi, 2017; Miller, 1995; Natale, Aunola, \& Nurmi, 2009; Räty, Vänskä, Kasanen, \& Kärkkäinen, 2002; Tõeväli \& Kikas, 2017).

\section{Başarı ve Başarısılıkla ilgili Nedensel Yüklemeler}

Nedensel yükleme (casual attributions), kişinin kendisinin ya da başkalarının davranışlarını açıklama ve değerlendirme biçimini göstermektedir. Başarı ve başarısızlıkla ilgili nedensel yüklemeler ise, Weiner (2010)'a göre, insanların kendilerinin ya da başkalarının başarı ve başarısızlıklarını nasıl açıkladıkları ile ilgilidir. Weiner (2010), insanların başarı/başarısızlık ile ilgili yüklemelerinin üç boyutta ele alınabileceğini belirtmektedir. Bunlardan ilki, kontrol odağı (locus of control)'dır. Buna göre, bireyin başarı-başarısızlık durumunda ilk sorduğu bunun içsel mi yoksa dışsal bir etmenle mi açıklanabileceğidir. Örneğin, bir anne çocuğunun herhangi bir dersteki başarısını, onun çok çalışması (içsel) ve başka bir dersteki başarısızlığını ise öğretmenin ona yeterince ilgi göstermemesi (dışsal) gibi bir kaynağa yükleyerek açıklayabilir. İkincisi başarı-başarısızlıkla ilgili açıklamanın değişebilirliği (stability) ile ilgilidir. Buna göre bir baba çocuğunun dersteki başarısının zeki olduğu için beklendik (sürekli) bir durum olduğunu ya da bir başka baba çocuğunun başarısızlığını ergenlik dönemine girmiş olduğu için okula ve öğrenmeye ilgisiz olması (süreksiz/değişebilir) ile açıklayabilir. Weiner (2010)'ın bahsettiği son etmen, başarı ya da başarısızlığın kontrol edilebilir olup olmadığı ile ilgilidir. Buna göre, anne eğer derslerine düzenli çalışırsa çocuğunun başarılı olabileceğini (kontrol edilebilir) ya da çocuğunun en fazla ortaokuldan mezun olabilecek yeterliliğe (kontrol edilemez) sahip olduğu için başarılı olamayacağını düşünebilir. Bu boyutlara ek olarak başarı başarısızlık durumunda kişilerin, durumu olası dört etmene bağlı olarak açıkladıkları üzerinde durulmaktadır. Buna göre; değişmez, kontrol edilemez ve içsel bir özellik olarak yetenek; değişebilir, kontrol edilebilir ve içsel bir özellik olarak çaba; değişebilir, kontrol edilemez ve dışsal bir özellik olarak öğretim stratejileri/öğretmen yeterliliği ve son olarak değişebilir, kontrol edilemez ve dışsal bir etmen 
olarak şans değişkenleri ile tanımlanmaktadır. Weiner (2010) ana babanın başarıya dönük yüklemelerinin, çocuklarının gelecekteki başarısına yönelik beklentilerini ve duygularını etkilediğini öne sürmektedir. Üstelik bu beklenti ve duyguların, anne babaların çocuk yetiştirme stilleri yanında çocuklarına sundukları toplumsal ve fiziksel çevreyi de etkilediği için çocuğun akademik başarısı üzerinde doğrudan ve dolaylı etkileri olduğu iddia edilmektedir. Bu görüşleri destekler biçimde, alanyazında da ana babaların çocuklarının eğitimi ile ilgili beklenti ve davranışlarının, akademik başarı üzerinde etkili olan en önemli değişken olduğu (Jeynes, 2005, 2007); üstelik bu beklenti ve davranışlarla ana babaların başarıya dönük yüklemeleri arasında da pozitif yönde anlamlı ilişkiler olduğu ortaya konmuştur (Georgiou, 1999; Natale et al., 2009; Tõeväli \& Kikas, 2017).

Ana babaların başarı ve başarısızlık ile ilgili nedensel yüklemeleri, farklı etmenlere bağlı olarak değişebilmektedir. Alanyazın eğitim düzeyi yüksek ana babaların düşük olanlara, annelerin babalara ve batılı toplumların Asya toplumlarına göre başarıyı, daha çok yetenek yoluyla açıkladıklarını göstermektedir (Enlund et al., 2017; Phillipson, 2006; Rytkönen et al., 2005). Buna ek olarak nedensel yüklemeler, çocuğun cinsiyetine ve yaşına bağlı olarak da değişebilmektedir. Örneğin Räty vd. (2002), erkeklerin matematik alanında gösterdiği başarının yetenekle, kızların aynı alandaki başarısının daha çok çaba açıklandığını; bununla birlikte sözel alandaki nedensel yüklemeler incelendiğinde, kızların bu alandaki başarılarının yetenek, erkeklerin ise çabaya yükleme yapılarak açıklandığını ortaya koymuştur. Aynı çalışmada, çocukların önceki performans düzeyinin ana babaların başarı-başarısızlığa yönelik yüklemelerini etkilediği; genelde başarılı olan öğrencilerin matematik dersinde gösterdiği başarının yetenek ile açıklanırken, ortalama veya vasat bir öğrencinin matematik başarısının ise çaba ile açıklandığı belirlenmiştir. Bu bulgu Kinlaw, Kurtz-Costes ve Goldman-Fraser (2001) ve Natale vd. (2009)'nin çalışmaları ile de desteklenmektedir. Çalışmalarda, başarının daha çok yetenekle, başarısızlığın ise daha çok çaba ile açıklandığı belirtilmektedir. Miller (1995) ve Philipson (2006), ana babalar için başarısızlığı, yetenek yokluğu gibi bir nedenle açıklamanın duygusal olarak kolay olmayabileceği; bunun yerine çabanın daha kolay baş edilebilir bir durum olduğu biçiminde yorumlamaktadır. Buna ek olarak, Enlund vd. (2017), Kinlaw vd. (2001), Miller (1995), Rytkönen vd. (2005) ve Räty vd. (2002), başarı ya da başarısızlığın görev zorluğu/öğretim stratejileri ve şansa yüklenerek açıklanma olasılığının ise genellikle çok düşük olduğunu belirtmektedirler. Philipson ve Philipson (2010), başarı ve başarısızlığa yönelik yüklemelerin şans (en zor) ile çaba (en kolay) arasında değişen bir süreklilik içerisinde değerlendirildiğini belirtmektedir.

Alanyazında ana babaların bahsedilen yüklemelerinin, çocukların okul ve eğitimle ilgili davranış ve bilişleri üzerindeki etkileri ile ilgili çalışmalara da rastlanmaktadır. Aunola vd. (2002), Enlund vd. (2017), Miller (1995) ve Natale vd. (2009); ana babaların başarı-başarısızlıkla ilgili yüklemelerinin, çocukların daha sonraki başarıları, başarıya dönük güdüleri ile başarıya dönük özyeterlilik duyguları üzerinde etkili olduğunu belirtmektedir. Buna göre, başarının yetenekle açıklandığı durumlarda, öğrenci başarısının öncekine göre arttığı, aksine çabaya yükleme yapılan durumlarda ise başarı ve akademik güdünün düştüğü belirlenmiştir. Bunun olası bir nedeni, Weiner (2010)'ın da vurguladığı gibi, ana babanın olumlu yüklemelerinin çocuğun kendi yeteneklerine olan inancını güçlendirmesi ve bunun akademik başarının artmasına yardımcı olan önemli bir değişken olmasıdır. Ancak bu durumun, Phillipson'ın (2006) da vurguladığı gibi, ana babaların başarıya dönük yüklemeleri ve çocuklarının başarısı ile ilgili beklentileri arasındaki ilişki ile açıklanabileceği de düşünülmektedir. Çalışmada, çocuklarının akademik başarısını, yetenek ile açıklamak yerine dışsal, kontrol edilebilir veya değişebilir bir nedene yükleyerek açıklayan ana babaların, çocuklarının gelecekteki eğitimleri ve başarıları ile ilgili beklentilerinin de düşük olduğundan bahsedilmektedir. Miller (1995), Natale vd. (2009), çocuğun akademik başarısı ile ilgili bu düşük beklentilerin, günlük yaşamda ana baba-çocuk arasında gerek okul gerekse görev temelli tüm etkileşimlerde, sözel ve davranışsal olarak çocuğa aktarıldığını belirtmektedir. Araştırmacılar, düşük beklentiyi içeren bu tür etkileşimlerin, çocuğun yeteneklerine yönelik benlik duygusunu ve aynı zamanda da okula dönük güdü düzeyini olumsuz yönde etkilemektedir. Ancak kimi çalışmalarda da ana babaların başarı ve başarısızıkla ilgili yüklemelerinin, onların çocukları ile kurdukları etkileşimlerin içerik ve biçimini etkilediğini gösteren çalışmalar da vardır. Rytkönen vd. (2005), çocuklarının okulda gösterdiği başarıyı yetenekle açıklayan ana babaların, çocuklarının okul çalışmalarına gösterdikleri destek ve katılımın 
arttığını, bunun da akademik başarı üzerinde olumlu yönde etkili olduğunu ortaya koymuştur. Buna ek olarak Weiner (2010) da, başarısızıı̆ın çabanın yokluğu gibi kontrol edilebilir dışsal bir nedene yüklenerek açıklandığı durumlarda, çocukların, suçluluk ve pişmanlık; kontrol edilemeyen yetenek gibi içsel bir nedene yüklendiği durumlarda ise utanç ve aşağılık duygusu yaşadıklarını iddia etmektedir. Bütün bu duygu durumları ise yukarıda da belirtildiği gibi, çocukların okul başarısını olumsuz yönde etkilemektedir.

\section{Araştırmanın Amacı ve Önemi}

Yapılan tarama da Türkçe alanyazında da ana babaların çocuğun eğitimindeki rolü ve özellikle akademik başarısı üzerindeki etkilerini vurgulayan araştırmalara rastlanmaktadır. Bu araştırmalarda, uluslararası alanyazını destekler nitelikte, genel olarak ana babaların çocuklarının eğitimine gösterdikleri destek, katılım ve özellikle ev temelli katılım ile çocukların akademik başarıları arasında olumlu yönde bir ilişki olduğu ortaya konmaktadır (Anıl, 2009; Erdogan \& Demirkasımoglu, 2010; İpek, 2011; Sabancı, 2009; Şad, 2012). Bununla birlikte, özellikle ana baba katılımına yönelik çalışmalarda gerek ana babaların gerekse öğretmen ve yöneticilerin katılımın önemi ve gerekliliğine inanıyor olmalarına rağmen, eğitimde ana baba katılımının sınırlı ve hatta yokluğunu ortaya koyan bulgular, bunun nedeni ile ilgili daha ayrıntılı incelemeler yapılmasını gerektirmektedir. Ancak alanyazında katılımı engelleyen ana babaya, okula, çocuğun kendisine özgü kimi özelliklere (eğitim düzeyi, sosyoekonomik düzey, çalışma durumu, işbirliğine açık olmama, katılımla ilgili olumsuz tutum gibi) değinilmekle birlikte (Basaran \& Koc, 2001; Ceylan \& Akar, 2011; Erdogan \& Demirkasımoglu, 2010; Keçeli-Kaysılı, 2002; Lindberg, 2013; Sabancı, 2009; Şad, 2012), üç çalışma dışında (Kaya \& Bacanlı, 2015; Lindberg, Yıldırım, Elvan, Öztürk \&Recepoğlu, 2019; Tekin, 2016) ana babaların çocuklarının eğitimindeki rolleri ile ilgili inanç ve değerleri ve özelde de başarıya dönük kişisel ve kültürel temelli yüklemelerini belirlemeye yönelik herhangi bir çalışmaya rastlanmamıştır. Kaya ve Bacanlı (2015)'nın çalışmasında, ana babaların çocuklarının eğitimine katılımları ile ilgili rol ve yeterlilik algıları üzerinde durulmuştur. Çalışmada, ana babaların çocuklarının eğitimini desteklemeye yönelik özyeterlilik düzeylerinin, çocuklarının eğitimlerinde önemli olduklarına yönelik rollerini kabul ediyor olmalarının ve ayrıca kendi geçmiş okul deneyimlerinin olumlu olmasının onların çocuklarının eğitimine katılımlarını da arttırdığı belirlenmiştir. Lindberg vd. (2019)'nun çalışması ise görüşmeye dayalı nitel bir çalışma olarak desenlenmiştir. Çalışmada, ana babaların çocuklarının eğitsel geleceği ile ilgili beklentileri üzerinde durulmuştur. Çalışmada çoğunlukla annelerden oluşan çalışma grubunun, çocukları ile ilgili beklenti düzeylerinin çocuklarının var olan başarı düzeyinden çok, katılımcıların çocukları ile ilgili kişisel istekleri ile biçimlendiği ortaya konmuştur. Çalışmanın bir diğer önemli bulgusu da ana babaların çocuklarının okulda başarılı olacağına ilişkin beklentilerinden ve bu beklentinin de çocuklarının okul çalışmalarına yönelik yetenek ya da çabalarına olan inançlarından kaynaklandığının belirlenmiş olmasıdır.

Türkçe alanyazında ana babaların başarı ve başarısızlığa bilişlerinden biri ve kültürel temelleri olan nedensel yüklemelerini ortaya koymaya yönelik herhangi bir ölçme aracına rastlanmamıştır. Bu doğrultuda bu çalışmada Philipson ve Philipson (2010) tarafından geliştirilen Ebeveyn Başarıya Dönük Nedensel Yükleme Ölçeği (ENEYÖ)'nin Türk kültürü ve diline uyarlanması amaçlanmıştır. Bu çalışmanın, yukarıda özetlenen alanyazın temelinde, iki nedenden dolayı önemli olduğuna inanılmaktadır. Bunlardan ilki çalışma kapsamında uyarlaması yapılan ölçek yoluyla, Türk ana babaların, çocuklarının başarı ve başarısızlıkla ilgili kişisel olduğu kadar sosyo-kültürel temelleri de çok güçlü olan nedensel yüklemelerinin belirlenmesi mümkün olabilecektir. Çünkü yukarıda belirtildiği gibi bu nedensel yüklemeler, ana babaların çocukları ile kurdukları tüm akademik ve sosyal ilişkileri ve dolayısıyla çocukların okul performanslarını, okula yönelik güdülerini ve sonuç olarak akademik başarılarını etkilemektedir. İkinci olarak, bu çalışmanın, uyarlaması yapılan ölçek kullanılarak yapılacak ileri düzey uygulamalı araştırmalar yoluyla, ana babaların çocuklarının okul başarısındaki etkilerini ve aynı zamanda bu etkiyi olumlu yönde geliştirmeye yönelik çalışmalara katkı sağlayacak olması nedeniyle de önemli olduğuna inanılmaktadır. 


\section{Yöntem}

\section{Çalışma Grubu}

Araştırmanın veri toplama sürecinde kültürel ve bağlamsal faktörlerin olası etkilerini kontrol edebilmek için Türkiye'nin farklı bölgelerinde yaşayan toplam 340 ana babaya ulaşılmıştır. Ana babaların 100'ü (\%29) Marmara ve Ege bölgesinde; 110'u (\%32.3) Orta Anadolu, 80'i (\%23.5) Karadeniz ve 50'si (\%14.7) Doğu Anadolu bölgesinde yaşamaktadır. Buna ek olarak 48’i (\%14.1) büyükşehir, 225’i (\%66.2) il merkezi, 67'si (\%19.8) ilçe ve daha küçük yerleşim yerlerinde yaşadıklarını belirtmişlerdir.

Katılımcılardan $235^{\prime} i$ anne (\%69) ve 105'i de (\%30.9) babadır ve 128'i (\%37.7) 20-35 yaş aralığında, 102 'si (\%30) 36-40 yaş arasındayken, 110'u (\%32.4) ise 40 yaş ve üzerindedir. Ana babaların 83'ü (\%24.4) ilk ve ortaokul mezunu, 75'i (\%22.1) lise, 182'si (\%53.5) üniversite mezunudur. Katılımcıların aylık gelir düzeyi ilgili analizler, katılımcıların 41'nin (\%12.1) aylık 2000 TL ve altı, 98'nin (\%28.8) 2001-4000 TL arası, 79'nun (\%23.2) 4001-6000 TL arası, 59'nun (\%17.4) 6001-8000 TL arası ve son olarak 63'nün (\%18.5) 8001 TL ve üstü aylık gelirinin olduğu belirlenmiştir. Katılımcılardan 178'nin (\%52.4) çocuğu ilkokul, 100’nün (\%29.4) çocuğu ortaokul ve 62'sinin (\%18.2) çocuğu da lise düzeyinde eğitim görmektedir.

\section{Veri Toplama Araçları}

Ana babaların, çocuklarının, okul çalışmalarındaki başarı ve başarısızlıklarının nedenlerine ilişkin yüklemelerini ölçmek için Phillipson ve Phillipson (2010) tarafından geliştirilen ENEYÖ, 24 maddelik bir ölçektir. ENEYÖ’deki maddeler hem başarı hem başarısızlıkla ilgili yetenek, çaba, strateji kullanımı ve şans boyutları ile ilgili yüklemeleri içeren betimlemeler içermektedir. Bu doğrultuda boyutlar; BaşarıŞans, Başarı-Yetenek, Başarı-Çaba, Başarı-Strateji, Başarısızlık-Şanssızıı, Başarısızlık-Yetenek, BaşarısızlıkÇaba, Başarısızlık-Strateji biçiminde belirtilmektedir. Örneğin "Çocuğum sınavlarda başarılı olduğunda, bu büyük olasılıkla şanslı olduğu içindir" maddesi Başarı-Şans boyutu altında, "Çocuğum okuldaki Matematik sınavından kötü not alırsa, bu büyük olasılıkla bu konuda iyi olmadığı içindir." maddesi ise Başarısızlık-Yetenek boyutu altında yer almaktadır. Ana babalardan, ölçekteki her bir madde ile ilgili değerlendirmelerini, Kesinlikle katılmıyorum (1) ile Kesinlikle katılıyorum (5) arasında değişen 5'li likert tipi ölçek üzerinde belirtmeleri istenmektedir. Ölçeğin yukarıda bahsedilen geliştirilme amacı ve dayandığı temel kuramsal yapısı ile uyumlu biçimde, ölçek uygulaması sonucunda her bir alt boyut için ayrı bir puan elde edilmektedir. Buna göre her bir boyuttan alınabilecek en yüksek puan 15, en düşük puan ise 3'dür. Örneğin Başarı-Şans boyutu ile ilgili yüksek puan, ana babanın, çocuğunun başarısını açıklarken şans faktörüne daha fazla yükleme yaptığı biçiminde yorumlanmaktadır.

Özgün ölçeğin sekiz boyutlu yapısının kuramsal yapıya uygunluğunu belirlemek için Doğrulayıcı Faktör Analizi kullanılmıştır. Yapılan analiz sonucunda ölçeğin; her bir boyutunda üç maddenin olduğu, orta - geniş aralığında değişen R2 değerlerine sahip ve her bir faktöre yüklenen maddelere ait regresyon katsayıları temelinde sekiz boyutlu yapısının doğrulandığı belirtilmektedir (Phillipson \& Phillipson, 2010). Elde edilen DFA sonuçlarının veri ile uyumuna ilişkin yapılan analizlerde; $\chi 2$ 'nin serbestlik derecesine oranı (X2/sd) 1.56, GFI=.90, CFI=.94, RMSEA= .05 olarak hesaplanmıştır. Bunun yanında 24 maddelik ölçeğin tamamı için hesaplanan Cronbach alpha değeri, .78'dir. Çalışmada, doğrusal olmayan ham puanların, standardize edilmiş artık değerler biçiminde, doğrusal olanlara dönüştürülmesini sağlayacak ortalamaları elde etmek için Rasch analizi kullanılmıştır. Rasch yoluyla analiz edilen maddelere ilişkin bu artık değerler, Doğrulayıcı Faktör Analizinde her bir maddenin uygun boyuta yüklenme şansının artmasına katkı sağlamıştır. Ayrıca ölçekte yer alan dereceleme ölçeğinin fonksiyonel olarak işleyip işlemediğini belirlemek için de dereceleme ölçeği modeline dayanan Rasch analizi kullanılmıştır. Analiz sonucunda hem uyum içi hem uyum dışı istatistikleri .99 olarak belirlenmiştir. Uyum içi ve uyum dışı $t$ değerleri de .00 olarak hesaplanmış; bu değer de veri model uyumuna ilişkin bir diğer sonuç olarak kabul edilmiştir. Madde yüzeyine ilişkin güvenirlik katsayısı .99 olarak belirlenmiş; bu değer, maddelerin güçlük düzeylerinin birbirinden farklı olduğu biçiminde yorumlanmıştır. Bireysel yeteneğe ilişkin tahmini ortalama -.21 olarak belirlenmiş; bu sonuç örneklemdeki 215 katılımcının maddeleri göreli olarak kolay bulduğu biçiminde açıklanmıştır. Bir anlamda bu durum, ana babalara, çocukları ile ilgili yüklemelerini ortaya koyabilecek yetenek düzeyinde oldukları konusunda güvenilebileceğini ortaya koymuştur. Birey 
düzeyindeki uyum ölçülerinde, uyum içi ortalama kareler ortalaması 1.00 ve uyumdışı ortalama kareler ortalaması da .99 olarak belirlenmiştir. Bu ölçümde uyum içi ve uyumdışı t değeri -.30 olarak belirlenmiş; bu sonuç, birey yüzeyine ilişkin güvenirlik katsayısının .75 olması nedeniyle kabul edilebilir bir uyumun işareti olarak kabul edilmiştir (Phillipson \& Phillipson, 2010).

\section{Verilerin Toplanması}

Katılımcılara gerek araştırmacı gerekse ilgili bölge ya da şehirdeki Eğitim Fakültelerinde görevli öğretim elemanlarının tanıdığı okul ya da sınıf rehber öğretmenleri veya branş öğretmenleri aracılığıyla ulaşılmıştır. Veri toplama sürecinden önce, veri toplama sürecinde ana babalara ulaşılmasına aracılık edecek öğretmenlerle görüşülmüş; araştırmanın amacı, verilerin nasıl kullanılacağı ile ilgili bilgi verilmiştir. Bu bilgilendirme sonrasında katılımcılarla ilgili demografik bilgileri içeren sorular ve veri toplama aracına ait maddeleri içeren online formun linki öğretmenlere iletilmiştir. Online form'da öncelikle araştırmanın amacı ve verilerin nasıl ve nerede kullanılacağı ile bilgiler verilmiş; sonrasında da kişisel bilgilerin güvenirliliğini sağlamaya yönelik önlemlerden bahsedilmiştir. Buna göre formda cevaplayanın kime ait olduğunu gösterecek hiçbir sorunun bulunmadığı, yanıtların online doldurulup gönderildiği için cevaplayan ile cevaplar arasında herhangi bir bağlantı kurulmasının mümkün olmadığı bilgileri verilmiştir. Son olarak bu bölümde, araştırmaya katılımın gönüllü olduğu; bununla birlikte online formun doldurulup gönderilmesinin araştırmanın amacı, içeriği ile ilgili bilgi edinildiği ve bilgilerin araştırmacı tarafından kullanımının kabul edildiğine ilişkin kabul onayı biçiminde yorumlanacağı belirtilmiştir.

\section{Verilerin Analizi}

Bu çalışmada, doğrulayıcı faktör analizi (DFA) öncesinde, veri setininin ilgili analiz için uygun olup olmadığının belirlenebilmesine yönelik sayıltılar incelenmiştir. Kline (1994), DFA'nın uygulanabilmesi için, örneklem büyüklüğünün en az 200 olması gerektiğini belirtmektedir. Bu çalışmada 340 kişilik bir örneklem grubuna ulaşılmıştır. DFA için belirtilen ikinci varsayım kayıp değerler ile ilgilidir. Veri seti kayıp değerler için incelenmiş, kayıp değer olmadığı belirlenmiştir. Çok değişkenli uç değerler için Mahalanobis uzaklıkları incelenmiştir. Buna göre, 44 kişiye ait gözlemin ki kare değerinin .01'den büyük olduğu belirlenmiş; bu nedenle bu kişilere ilişkin ölçümler veri setinden çıkarılmıştır. Bu işlemin arkasından verinin çok değişkenli normal dağılım gösterip göstermediği incelenmiştir. Çok değişkenli normallik için Relative Multivarite Kurtosis (RMK) değerine bakılmıştır. Yapılan incelemede RMK değeri, 1,152 olarak hesaplanmıştır. Bu indeks için, standart bir kesim noktası belirtilmemekle birlikte (Jöreskog \& Sörbom, 1993) Pellegrini ve Scandura (2005) bu değerin 3'ten küçük olmasının çok değişkenli normallik açısından kabul edilebilir bir düzey olduğunu belirtmektedir. Doğrusallık için saçılma diyagramı incelenmiş, verinin doğrusallıktan aşırı sapmadığı gözlenmiştir. Son olarak DFA öncesi değişkenler arasındaki çoklu bağlantılılık durumu da incelenmiştir. Yapılan incelemeler sonunda değişkenlere ilişkin VIF değerinin 10 'dan oldukça düşük olduğu; bu durumda da eldeki veriler için çoklu bağlantı sorununun olmadığı sonucuna varılmıştır.

\section{Bulgular}

\section{ENEYÖ’nün Çeviri Süreci ve Kapsam Geçerliği}

Ölçeğin uyarlama sürecinde Hambelton ve Patsula (1998) tarafından belirtilen uyarlama basamakları izlenmiştir. Buna göre, ölçeği geliştiren araştırmacılarla e-posta yoluyla yapılan görüşmelerden sonra hem ölçeğin yapısal özelliklerinin uyarlama yapılacak kültür ve dil için uygun olduğu kararı verilmiş hem de ölçeğin Türkçeye uyarlanabilmesi için araştırmacılardan izin alınmıştır. Bu aşamadan sonra ölçek Eğitim Psikolojisi alanında doktora derecesine sahip ve her iki dile hakim üç uzman tarafından Ingilizce'den Türkçe'ye çevrilmiştir. Bu ilk çeviriler sonrasında yapılan tüm çeviriler, çeviriyi yapan uzmanların tamamının katıldığı bir toplantıda tek tek incelenmiştir. Bu incelemede, her bir maddenin çevirisi ile ilgili farklılıklar üzerinde durulmuş; bu farklılıkları ortadan kaldırmaya yönelik çeviri önerilerine göre ölçeğe ilk şekli verilmiştir. Bu süreçte, ölçeğin 15. (Çocuğum okulun heceleme sınavında sonuncu olduğunda, bunun nedeni büyük olasılıkla şanslı olmamasıdır.) ve 18. (Çocuğum okuldaki heceleme 
sınavında kötü not aldığında, bu büyük olasılıkla bu konuda iyi olmadığı içindir) maddelerinde yer alan ve İngilizce dilindeki kelimelerin hecelenmesi ile ilgili başarıya dönük ana baba yüklemelerini ortaya koymayı amaçlayan ifadeler için, çeviri grubundaki uzmanların önerileri doğrultusunda, Eğitim Programları ve Öğretimi ile Eğitimde Ölçme ve Değerlendirme alanlarından birer Doktoralı uzmana danışılmıştır. Belirtilen alanlardan uzmanların önerileri doğrultusunda Heceleme testi'nin Türkçe formda Matematik testi olarak kullanılmasının uygun olduğuna karar verilmiştir. Böylece ölçeğin 24 maddesi korunarak Türkçeye çeviri süreci tamamlanmıştır.

\section{ENEYÖ Uygulaması ile ilgili Betimsel İstatistikler}

Çeviri sürecinin tamamlanmasından sonra ölçek, 340 kişilik bir örneklem grubuna uygulanmıştır. Ancak veri setinin DFA için uygunluğunu belirlemek için yapılan ön inceleme sürecinde, daha önce de belirtildiği gibi uç değerler ile ilgili analizlerde, 44 kişiye ait verilerin veri setinden çıkarılmasının uygun olduğuna karar verilmiştir. Böylece analizler, 296 kişi üzerinden gerçekleştirilmiştir. Veri seti ile ilgili betimsel istatistikler Tablo 1'de verilmiştir.

Tablo 1.

ENEYÖ Maddelerine Ilişkin Hesaplanan Betimsel istatistikler.

\begin{tabular}{|c|c|c|c|c|c|c|c|}
\hline & $\overline{\mathbf{x}}$ & Mod & Medyan & SS & Min. & Max. & $\begin{array}{c}\text { Madde } \\
\text { Toplam } \\
\text { Korelasyonu }\end{array}$ \\
\hline \multicolumn{8}{|c|}{ 1.Boyut - Başarı-Şans } \\
\hline M1 & 1.70 & 1.00 & 1.00 & 1.09 & 1 & 5 & .61 \\
\hline M2 & 1.47 & 1.00 & 1.00 & 0.78 & 1 & 5 & .79 \\
\hline M3 & 1.45 & 1.00 & 1.00 & 0.80 & 1 & 5 & .77 \\
\hline \multicolumn{8}{|c|}{ 2.Boyut - Başarı-Yetenek } \\
\hline M4 & 3.16 & 4.00 & 3.00 & 1.29 & 1 & 5 & .66 \\
\hline M5 & 3.45 & 4.00 & 4.00 & 1.23 & 1 & 5 & .84 \\
\hline M6 & 3.54 & 4.00 & 4.00 & 1.23 & 1 & 5 & .81 \\
\hline \multicolumn{8}{|c|}{ 3.Boyut - Başarı-Çaba } \\
\hline M7 & 4.27 & 4.00 & 5.00 & 0.93 & 1 & 5 & .79 \\
\hline M8 & 4.35 & 5.00 & 5.00 & 0.86 & 1 & 5 & .84 \\
\hline M9 & 4.09 & 4.00 & 4.00 & 0.96 & 1 & 5 & .69 \\
\hline \multicolumn{8}{|c|}{ 4.Boyut - Başarı-Strateji } \\
\hline M10 & 4.42 & 5.00 & 5.00 & 0.81 & 1 & 5 & .78 \\
\hline M11 & 4.31 & 5.00 & 5.00 & 0.88 & 1 & 5 & .87 \\
\hline M12 & 4.27 & 5.00 & 4.00 & 0.87 & 1 & 5 & .80 \\
\hline \multicolumn{8}{|c|}{ 5.Boyut - Başarısızlık - Şans } \\
\hline M13 & 1.58 & 1.00 & 1.00 & 0.88 & 1 & 5 & .80 \\
\hline M14 & 1.54 & 1.00 & 1.00 & 0.90 & 1 & 5 & .90 \\
\hline. $\mathrm{M} 15$ & 1.61 & 1.00 & 1.00 & 1.01 & 1 & 5 & .83 \\
\hline \multicolumn{8}{|c|}{ 6.Boyut - Başarısızlık - Yetenek } \\
\hline M16 & 3.04 & 4.00 & 3.00 & 1.29 & 1 & 5 & .46 \\
\hline M17 & 2.65 & 2.00 & 2.00 & 1.28 & 1 & 5 & .43 \\
\hline M18 & 3.30 & 4.00 & 4.00 & 1.28 & 1 & 5 & .52 \\
\hline \multicolumn{8}{|c|}{ 7.Boyut - Başarısızlık - Çaba } \\
\hline M19 & 4.06 & 4.00 & 4.00 & 0.95 & 1 & 5 & .72 \\
\hline M20 & 3.99 & 4.00 & 4.00 & 0.95 & 1 & 5 & .78 \\
\hline M21 & 4.12 & 4.00 & 4.00 & 0.91 & 1 & 5 & .84 \\
\hline \multicolumn{8}{|c|}{ 8.Boyut - Başarısızlık - Strateji } \\
\hline M22 & 3.67 & 4.00 & 4.00 & 1.12 & 1 & 5 & .61 \\
\hline M23 & 3.93 & 4.00 & 4.00 & 0.97 & 1 & 5 & .77 \\
\hline M24 & 3.88 & 4.00 & 4.00 & 1.02 & 1 & 5 & .74 \\
\hline
\end{tabular}


Yürütülen analizler sonucunda, Tablo 1'de de görüldüğü gibi ENEYÖ’nün her bir maddesi için hesaplanan puanların ortalaması, 1.45 ile 4.42 arasında değişmektedir. Ölçekteki her bir maddenin ayırt ediciliğini belirlemek için madde toplam korelasyonları hesaplanmış; ayırt edicilik değerlerinin 0.43 ile 0.90 arasında değiştiği görülmektedir. Düzeltilmiş madde toplam korelasyonu ile ilgili olarak .30'dan büyük olan değerlerin kabul sınırlarında olduğu belirtilmektedir (Büyüköztürk, 2011). Bu çalışmada elde edilen sonuçlar doğrultusunda, ölçek maddelerinin tamamının ilgili boyut temelinde yüksek ayırt edicilik gücüne sahip olduğu anlaşılmaktadır.

\section{ENEYÖ’nün Geçerliliği ve Güvenirliliği}

Özgün ölçeğin 24 maddelik Türkçe formunun sekiz faktörlü yapısı için oluşturulan modelin veriye uyumunu incelemek için yapılan DFA'ya yönelik path diyagramı Şekil 1'de yer almaktadır.

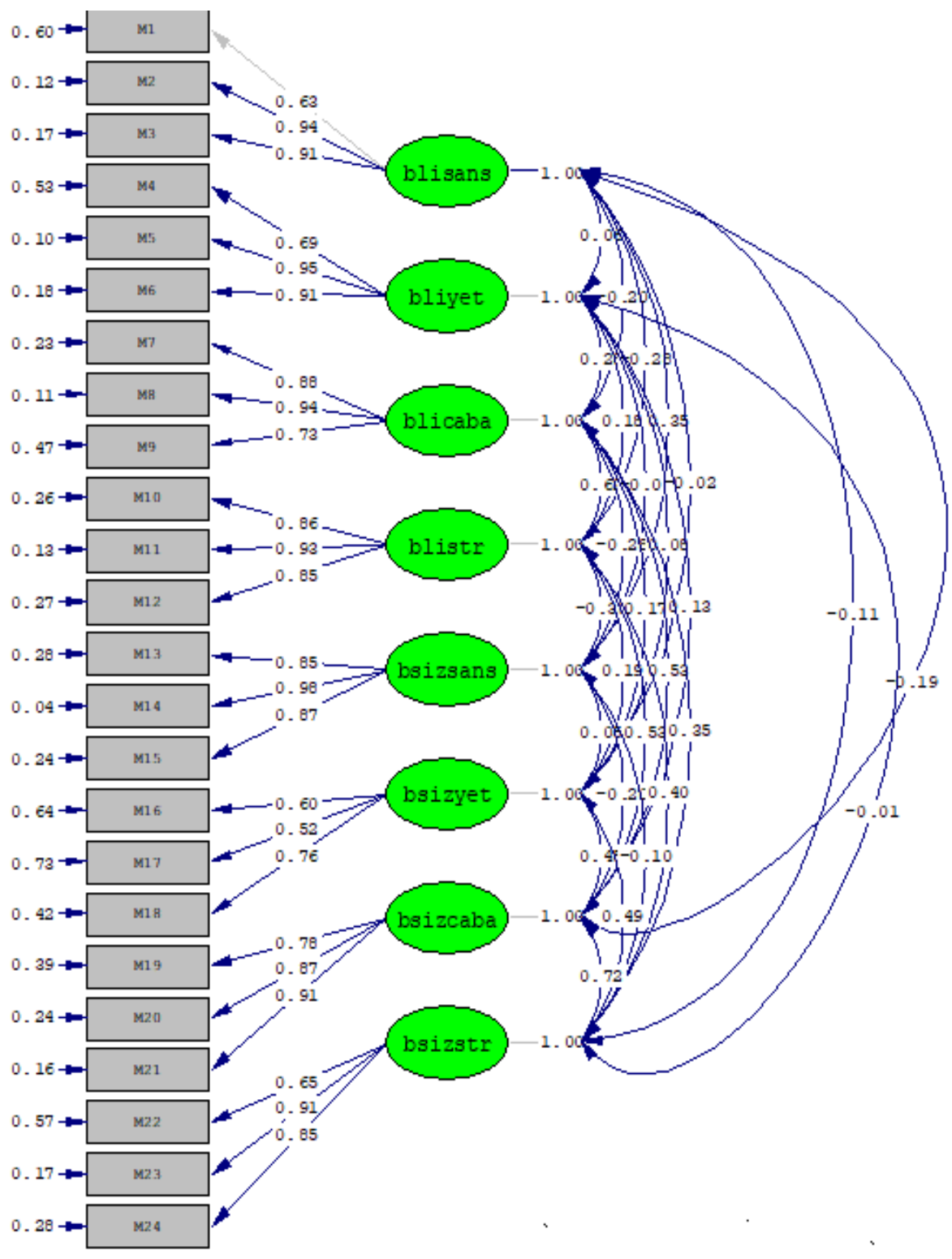

Şekil 1. Ana babaların çocuklarının okuldaki başarı ve başarısızlıkları ile ilgili çaba, yetenek, strateji ve şans temelli nedensel yüklemelerini gösteren sekiz faktörlü Ebeveyn Nedensel Yükleme Ölçeği modeli. 
Şekil 1'de görüldüğü üzere ölçeğin sekiz boyut ve 24 maddeden oluşan yapısının test edildiği DFA sonucunda, madde faktör yük değerlerinin ( $\lambda$ ) .52 ile .95 arasında değiştiği belirlenmiştir. Analiz sonucunda elde edilen $t$ değerlerinin .05 anlamlılık düzeyinde manidar olduğu, maddelere ait hata varyanslarının da .04 ile .73 arasında değiştiği belirlenmiştir. Standartlaştııı ış̧ beta katsayıları ise .52 .98 aralığındadır. Bu sonuçlardan hareketle, ölçek maddelerinden herhangi birinin çıkarılmasına gerek olmadığına karar verilmiştir.

ENEYÖ'den elde edilen DFA sonuçlarının veri ile uyumuna ilişkin istatistikler ise Tablo 2'de verilmiştir.

Tablo 2.

Doğrulayıcı Faktör Analizi Sonuçları.

\begin{tabular}{crrrrrrr}
\hline $\mathbf{2}$ & sd & $\mathbf{X}$ 2/sd & RMSEA & SRMR & CFI & GFI & Cronbach Alpha \\
\hline 432.11 & 224 & 1.92 & .056 & .053 & .97 & .89 & .80 \\
\hline
\end{tabular}

Tablo 2'de görüldüğü gibi, başta $\chi 2 / s d$ olmak üzere uyum iyiliği indekslerine ait tüm değerler, kabul aralıklarında yer almaktadır. Bu doğrultuda ölçek maddelerinin, ana babaların başarıya dönük yüklemelerini ölçmeyi amaçlayan yapının iyi birer temsilcisi olduğu; ayrıca maddelerin veriyle uyumlu olması nedeniyle de ENEYÖ yoluyla elde edilen ölçümlerin yapı geçerliliğine sahip olduğu anlaşılmıştır. Bu sonuçlar, Phillipson ve Phillipson (2010)'nın özgün ölçek geliştirme çalışmasındaki sonuçlarla da uyumludur. Özgün ölçek geliştirme çalışmasında, x2/sd oranı 1.56, RMSEA 0.05, CFI 0.94 ve GFI 0.90 olarak belirtilmiştir.

ENEYÖ'de yer alan boyutlar arası korelasyonlar Tablo 3'te verilmiştir.

Tablo 3.

ENEYÖ'nün Alt Boyutları Arasındaki Pearson Korelasyon Katsayıları

\begin{tabular}{|c|c|c|c|c|c|c|c|c|c|}
\hline & & $\begin{array}{r}\text { Başarı } \\
\text { Şans }\end{array}$ & $\begin{array}{r}\text { Başarı } \\
\text { Yetenek }\end{array}$ & $\begin{array}{r}\text { Başarı } \\
\text { Çaba }\end{array}$ & $\begin{array}{r}\text { Başarı } \\
\text { Strateji }\end{array}$ & $\begin{array}{r}\text { Bsızlık } \\
\text { Şans }\end{array}$ & $\begin{array}{r}\text { Bsızlık } \\
\text { Yetenek }\end{array}$ & $\begin{array}{r}\text { Bsızlık } \\
\text { Çaba }\end{array}$ & $\begin{array}{r}\text { Bsızlık } \\
\text { Strateji }\end{array}$ \\
\hline $\begin{array}{l}\text { Başarı } \\
\text { Şans }\end{array}$ & $\begin{array}{l}\text { Pearson } \\
\text { Kor. Kat }\end{array}$ & 1 & 11 &,$- 14^{*}$ &,$- 22^{* *}$ &, $30^{* *}$ & -,004 &,$- 13^{*}$ & -,05 \\
\hline & $p$ & & ,05 & ,01 & ,000 & ,000 & 94 & 01 & ,31 \\
\hline $\begin{array}{l}\text { Başarı } \\
\text { Yetenek }\end{array}$ & $\begin{array}{l}\text { Pearson } \\
\text { Kor. Kat }\end{array}$ & & 1 &, $31^{* *}$ &, $18^{* *}$ & ,03 & 11 &, $13^{*}$ & -,01 \\
\hline & $p$ & & & ,000 & ,001 &, 52 & ,05 & ,02 & ,85 \\
\hline $\begin{array}{l}\text { Başarı } \\
\text { Çaba }\end{array}$ & $\begin{array}{l}\text { Pearson } \\
\text { Kor. Kat }\end{array}$ & & & 1 &, $57^{* *}$ &,$- 23^{* *}$ & ,11* &, $47^{* *}$ &, $31^{* *}$ \\
\hline & $p$ & & & & ,000 & ,000 & ,04 & ,000 & 000, \\
\hline $\begin{array}{l}\text { Başarı } \\
\text { Strateji }\end{array}$ & $\begin{array}{l}\text { Pearson } \\
\text { Kor. Kat }\end{array}$ & & & & 1 &,$- 35^{* *}$ & $11^{*}$ &, $49^{* *}$ &, $36^{* *}$ \\
\hline & $p$ & & & & & ,000 & 040 & 000, & 000, \\
\hline $\begin{array}{l}\text { Bsızlık } \\
\text { Şans }\end{array}$ & $\begin{array}{l}\text { Pearson } \\
\text { Kor. Kat }\end{array}$ & & & & & 1 & 07 &,$- 18^{* *}$ & -,09 \\
\hline & $p$ & & & & & & 197, & 002 & 104, \\
\hline Bsızlık & $\begin{array}{l}\text { Pearson } \\
\text { Kor. Kat }\end{array}$ & & & & & & 1 &, $34^{* *}$ &, $35^{* *}$ \\
\hline Yetenek & $p$ & & & & & & & , 000 & ,000 \\
\hline Bsızlık & $\begin{array}{l}\text { Pearson } \\
\text { Kor. Kat }\end{array}$ & & & & & & & 1 &, $63^{* *}$ \\
\hline Çaba & $p$ & & & & & & & & ,000 \\
\hline
\end{tabular}


Pearson Korelasyon Katsayıları ile ilgili analizler, boyutlar arasındaki düşük ve orta düzeyde; negatif ve pozitif yönde ilişkiler olduğunu göstermektedir. Bununla birlikte bazı boyutlar arasında anlamlı düzeyde herhangi bir ilişkinin olmadığı görülmektedir. Buna göre, Başarı-Şans boyutu ile BaşarısızlıkYetenek (-.004, p>0.05) ve Başarısızlık-Strateji (-,05, p>0.01); Başarı-Yetenek ile Başarısızıı-Şans ( ,03, $p>05)$ ve Başarısızlık-Strateji (- ,01, p>05); Başarısızlık-Şans ile Başarısızlık Yetenek (,07, $p>.05)$ ve Başarısızık-Strateji $(-, 09, p>.05)$ boyutları arasında anlamlı düzeyde bir ilişki bulunamamıştır. Bunun yanında elde edilen korelasyonların çok yüksek olmamasının, ölçek boyutları arasında çoklu bağlantılılık probleminin olmadığının bir göstergesi olarak değerlendirilebileceği düşünülmektedir (Dereli-Iman, 2013).

$\mathrm{Bu}$ çalışmada ölçeğin Cronbach Alfa iç tutarlılık katsayısı .80 olarak belirlenirken; Phillipson ve Phillipson (2010) bu katsayıyı .78 olarak rapor etmiştir.

\section{Tartışma ve Sonuç}

Bu çalışmanın amacı, ana babaların çocuklarının başarı ve başarısızııla ilgili yüklemelerini belirlemeyi amaçlayan ve Philipson ve Philipson (2010)tarafından geliştirilen Ebeveyn Başarıya Dönük Nedensel Yüklemeler ölçeğinin Türkçe'ye uyarlamasını yapmaktır. Ölçek, başarı ve başarısızlık genel boyutları altında; kuramsal yapı ile uyumlu biçimde Başarı-Yetenek, Başarı-Çaba, Başarı-Strateji, Başarı-Şans Boyutları ile Başarısızlık-Yetenek, Başarısızlık-Çaba, Başarısızlık-Strateji ve Başarısızlık-Şans olmak üzere sekiz alt boyuttan oluşmaktadır.

Özgün ölçeğe ait sekiz faktörlü yapının, Türk kültüründe doğrulanıp doğrulanmayacağını belirlemek üzere gerçekleştirilen DFA yoluyla elde edilen uyum indekslerinin sonuçları, model-veri uyumunu desteklemektedir. Analizler sonucunda, $\chi 2 / \mathrm{sd}=1.92, \mathrm{RMSEA}=.05, \mathrm{SRMR}=.05, \mathrm{CFI}=.97$ ve $\mathrm{GFI}=.89$ olarak belirlenmiştir. Alan yazında $\chi 2 /$ sd oranının 2 ve 3 'den küçük ya da ona eşit, RMSEA değerinin ise 0.060.08 aralığında, SRMR değerinin 0.08 'den küçük ya da ona eşit, CFI değerinin 0.90 ve üzeri, GFI değerinin 0.85 ve üzeri olmasının, modelin gerçek verilerle uyumuna yönelik kabul edilebilir alt sınırlar olarak kabul edilebileceği belirtilmektedir (Tabachnick ve Fidell, 2007). Bu çalışmada elde edilen sonuçlar, özgün ölçekten elde edilen sonuçlara paralel biçimde model veri arasındaki iyi ve hatta mükemmel uyumu destekler niteliktedir.

Özgün ölçeğin Cronbach alpha katsayısı, .78 olarak belirtilmiştir. Bu çalışmada ise ölçeğin Cronbach alpha katsayısı, .80 olarak belirlenmiştir. Alanyazında güvenirlilik değerlendirmesinde, Cronbach alpha katsayısının 1'e yakınlık düzeyinin önemli olduğu; değer 1'e yaklaştıkça ölçeğin güvenirliliğe ile ilgili güçlü bir kanıta sahip olunduğu belirtilmektedir. Bununla birlikte Cronbach alpha katsayısının .70'in altında ya da .90’nın üstünde olmasının, ölçeğin güvenirlilik düzeyi ile ilgili sorun olduğu biçiminde (Şencan, 2005). Bu çalışmada elde edilen değer, kabul sınırları arasındadır.

Daha önce belirtildiği gibi, bu uyarlama çalışmasıyla kurama dayalı olarak geliştirilen ( ana - babaların başarı ve başarısızlıkları ile ilgili yüklemeleri) modelin, doğrulanıp doğrulanmadığının belirlenmesi amaçlanmaktadır. Bu kapsamda DFA analizi gerçekleştirilmiş ve orijinal ölçekte tanımlanan yapı ile uyumlu olarak ölçeğin sekiz boyutlu yapısı doğrulanmış; bazı faktörler/boyutlar arasında ilişki bulunmuş ya da bazı faktörlerin ilişkisiz olduğu tespit edilmiştir. Boyutlar arasındaki ilişki, faktörlerin ayırıcılığına ilişkin önemli bilgiler vermektedir. Faktörler arasındaki korelasyon kestirimlerinin çok yüksek olması (0.85 ve üstü) ayırt edici geçerliği (discriminant validity) tehdit etmektedir (Kline, 2005). Buna göre, çalışmada faktörler arası anlamlı bulunan korelasyonların düşük ve orta düzeyde olması, ilgili faktörlerin ana - babaların başarı ve başarısızlıkları ile ilgili yüklemeleri ayrı ayrı ölçtüğünü göstermektedir (Çokluk, Şekercioğlu, Büyüköztürk, 2018). Bununla birlikte çalışmada; Başarı-Şans boyutu ile Başarısızlık-Yetenek ve Başarısızlık-Strateji; Başarı-Yetenek ile Başarısızık-Şans ve Başarısızlık-Strateji; Başarısızlık-Şans ile Başarısızlık Yetenek ve Başarısızıı-Strateji boyutları arasında anlamlı düzeyde herhangi bir ilişki bulunamamıştır. Ancak bu durum başlangıçtaki ölçme modeli tarafından desteklenmektedir. Buna ek olarak, Philipson ve Philipson (2010), ölçeğin her bir boyutunun ayrı ayrı ele alınabileceğini, ölçekten tek bir toplam puan hesaplanmayacağını belirtmiştir. Çalışmada DFA analizi sonuçları da model veri 
uyumunun sağlandı̆̆ını; değişkenlerin faktörlerle, faktörlerinde kendi aralarında öngörülen ilişkilerin doğrulandığını kanıtlamaktadır. Ölçeğin dayandığı temel model (Weiner, 2010) ve bu konudaki alanyazın (Lansford \& Bornstein, 2011; Miller, 1995; Phillipson \& Phillipson, 2010) akademik alandaki başarı ya da başarısızlığın olası dört farklı duruma atıf yapılarak açıklanabildiğini göstermektedir. Buna göre, akademik alandaki başarı ya da başarısızlığın nedeni; şans, çaba, yetenek ya da strateji temelinde yapılacak yüklemeler yoluyla açıklanabilmektedir. Bunun yanında alanyazın da ana babaların çocuklarının başarı ve başarısızlıklarını bir nedene bağlamaları gereken durumlarda, en fazla yükleme yaptıkları değişkenlerin de yetenek ve çaba olduğunu göstermektedir (Enlund et al., 2017; Kinlaw et al., 2001; Miller, 1995; Räty, Vänskä, et al., 2002; Rytkönen et al., 2005). Çalışmalarda hem başarı hem başarısızlığın şans faktörüne; başarısızlığın ise yetenek ya da stratejiye yükleme yapılarak açıklanmasının pek olası bir durum olmadığı ortaya konmaktadır. Bu sonucun olası nedeni, Phillipson ve Phillipson (2010) da belirttiği gibi, ana babaların, çocuklarıyla akademik başarı temelinde kurdukları iletişimlerinde çaba ve çalışma stratejisini daha fazla vurgularken, şansı daha az vurguluyor olmaları olabilir. Çünkü başarının, çaba ve strateji gibi günlük yaşamda daha kolay biçimde örneklendirilip, somutlaştırılabilir bir özelliğe dayanılarak açıklanması, şans gibi ölçülmesi ve somutlaştırılması zor olan dışsal ve kontrol edilemez bir özellikle açıklanmasından daha kolaydır. Üstelik özgün ölçeğin geliştirilmesi sürecinde yapılan Rasch analizinin sonuçları, ana babalar için yanıtlanması en zor maddelerin, başarı ve başarısızlığı şans durumuna ve ayrıca başarısızlığı da yetenek ve strateji durumlarına bağlayarak açıklamayı gerektirenler maddeler olduğunu ortaya koymuştur. Analizde, yanıtlanması en kolay maddeler ise, başarı ve başarısızlığı strateji ve çabaya yükleyerek açıklayan maddeler olarak belirlenmiştir. Buna göre bu ölçek uyarlama çalışmasında boyutlar arası ilişki örüntüsüne ilişkin elde edilen sonuçların, ölçeğin dayandığı temel kuramsal model ve alanyazın ile özgün ölçeğin geliştirilmesi sırasında elde edilen sonuçları da destekler nitelikte olduğu anlaşılmaktadır.

Sonuç olarak, ENEYÖ’nün Türkçe formunun, ana babaların çocuklarının akademik başarı ve başarısızlığı ile ilgili yüklemelerinin ölçülmesinde kullanılabilecek geçerli ve güvenilir bir ölçme aracı olduğu söylenebilir. Bu ölçek kullanılarak ana babaların, çocuklarının eğitimine katılımını, çocuklarına gösterdikleri desteği ya da rehberliği etkileyen ve bireysel olduğu kadar sosyokültürel düzeyde de önemli olan akademik başarı-başarısızlık yüklemelerinin betimlenmesi mümkün olabilir. Bu tür betimlemeler ise çocukların gelişim ve eğitiminde, ana babaların hem okul yönetici ve öğretmenlerinin hem de ana babaların gereklilik ve önemine inanılan, eğitimci ve katılımcı rollerinin geliştirilmesi ile ilgili çalışmalara katkı sağlayacaktır. 


\section{References}

Anıl, D. (2009). Uluslararası Öğrenci Başarılarını Değerlendirme Programı (PISA)'nda Türkiye'deki Öğrencilerin Fen Bilimleri Başarılarını Etkileyen Faktörler. Eğitim ve Bilim, 34(152), 87-100. http://egitimvebilim.ted.org.tr/index.php/EB/article/viewArticle/594

Aunola, K., Nurmi, J.-E., Niemi, P., Lerkkanen, M.-K., \& Rasku-Puttonen, H. (2002). Developmental dynamics of achievement strategies, reading performance, and parental beliefs. Reading Research Quarterly, 37(3), 310-327. https://doi.org/10.1598/rrq.37.3.3

Basaran, Semra; Koc, F. (2001). Ailenin Çocuğun Okuldaki Eğitimine Katılım Sorunları ve Katılımın Sağlanması için Alternatif bir Model. Ministry of Education.

Büyüköztürk, Ş. (2011). Sosyal bilimlerde veri analizi el kitabı: istatistik, araştırma deseni, SPSS uygulamaları ve yorum (13th ed.). Ankara: Pegem Publishing.

Ceylan, M., Akar, B., Dan, P., \& Lisesi, K. (2011). Ortaöğretimde Okul- Aile İşbirliği İle illgili Öğretmen ve Veli Görüşlerinin İncelenmesi (Karacasu Lisesi Örneği). Cankırı Karatekin University Journal of Institute of Social Sciences, 1(2), 43-64.

Çokluk, Ö., Şekercioğlu, G., \& Büyüköztürk, Ş. (2018). Sosyal bilimler için çok değişkenli istatistik: SPSS ve LISREL uygulamaları (5th ed.). Ankara: Pegem Publishing.

Dereli-Iman, E. (2013). Adaptation of social problem solving for children questionnaire in 6 age groups and its relationships with preschool behavior problems. Kuram Ve Uygulamada Egitim Bilimleri, 13(1), 491-498.

Enlund, E., Aunola, K., Tolvanen, A., Lerkkanen, M. K., \& Nurmi, J. E. (2017). Parental ability attributions regarding children's academic performance: Person-oriented approach on longitudinal data. Journal of Applied Developmental Psychology, 52(April), 12-23. https://doi.org/10.1016/j.appdev.2017.06.003

Erdogan, C; Demirkasımoglu, N. (2010). Teachers' and School Administrators' Views of Parent Involvement in Education Process. Educational Administration: Theory and Practice, 16(3), 399-431.

Fan, X.; Chen, M. (2001). Parental Involvement and Students' Academic Achievement: A Meta-Analysis. Educational Psychology Review, 13(1), 1-22.

Georgiou, S. N. (1999). Parental attributions as predictors of involvement and influences on child achievement. British Journal of Educational Psychology, 69(3), 409-429. https://doi.org/10.1348/000709999157806

Hambelton, Ronald K.; Patsula, L. (1998). Adapting Tests for Use in Multiple Languages and Cultures. Social Indicators Research, 45(1), 153-171.

İpek, C. (2011). The Effects of Parent's Educational Involvement, School Attitudes and Some Family Related Factors on the Primary School Students' National Level Assessment Test Scores. Pegem Egitim ve Ogretim Dergisi, 1(2).

Jeynes, W. H. (2005). A meta-analysis of the relation of parental involvement to urban elementary school student academic achievement. Urban Education, 40(3), 237-269. https://doi.org/10.1177/0042085905274540

Jeynes, W. H. (2007). The relationship between parental involvement and urban secondary school student academic achievement: A meta-analysis. Urban Education, 42(1), 82-110. https://doi.org/10.1177/0042085906293818

Jöreskog, K. G., \& Sörbom, D. (1993). LISREL 8: Structural equation modeling with the SIMPLIS command language. USA: Scientific Software International.

Kaya, Ö.; Bacanlı, K. (2015). Eğitim Yaşantısına Ebeveyn Katılım Algısını Açıklamaya Yönelik Bir Model Geliştirme. Hacettepe University Journal of Education, 31(2), 1-1.

Keçeli-Kaysılı, B. (2002). Akademik Başarının Arttırılmasında Aile Katılımı. Ankara Universitesi Egitim Bilimleri Fakultesi Ozel Egitim Dergisi, 069-083. https://doi.org/10.1501/ozlegt_0000000115 
Kinlaw, C. R., Kurtz-Costes, B., \& Goldman-Fraser, J. (2001). Mothers' achievement beliefs and behaviors and their children's school readiness: A cultural comparison. Journal of Applied Developmental Psychology, 22(5), 493-506. https://doi.org/10.1016/S0193-3973(01)00090-9

Kline, R. B. (2005). Principles and practice of structural equation modeling (2nd ed). New York: Guilford.

Lansford, J. E., \& Bornstein, M. H. (2011). Parenting attributions and attitudes in diverse cultural contexts: Introduction to the special issue. Parenting, 11(2-3), 87-101.

Lindberg, E. N. (2013). Turkish parents' and teachers' opinions towards parental participation in a rural area. Middle East Journal of Scientific Research, 17(3), 321-328.

Lindberg, E. N., Yıldırım, E., Elvan, Ö., Öztürk, D., \& Recepoğlu, S. (2019). Parents' Educational Expectations: Does It Matter for Academic Success? SDU International Journal of Educational Studies, 6(2), 150-160. https://doi.org/10.33710/sduijes.596569

Miller, S. A. (1995). Parents' Attributions for Their Children's Behavior. Child Development, 66(6), 15571584. https://doi.org/10.1111/j.1467-8624.1995.tb00952.x

Natale, K., Aunola, K., \& Nurmi, J. E. (2009). Children's school performance and their parents' causal attributions to ability and effort: A longitudinal study. Journal of Applied Developmental Psychology, 30(1), 14-22. https://doi.org/10.1016/j.appdev.2008.10.002

Pellegrini, E. K., \& Scandura, T. A. (2005). Construct equivalence across groups: An unexplored issue in mentoring research. Educational and Psychological Measurement, 65(2), 323-335.

Phillipson, S. (2006). Cultural variability in parent and child achievement attributions: A study from Hong Kong. Educational Psychology, 26(5), 625-642. https://doi.org/10.1080/01443410500390772

Phillipson, S., \& Phillipson, S. N. (2010). The involvement of Hong Kong parents in the education of their children: A validation of the Parents' Attributions and Perception Questionnaire. Educational Psychology, 30(6), 625-649. https://doi.org/10.1080/01443410.2010.496900

Phillipson, S., \& Phillipson, S. N. (2012). Children's cognitive ability and their academic achievement: The mediation effects of parental expectations. Asia Pacific Education Review, 13(3), 495-508.

Räty, H., Leinonen, T., \& Snellman, L. (2002). Parents' educational expectations and their socialpsychological patterning. Scandinavian Journal of Educational Research, 46(2), 129-144.

Räty, H., Vänskä, J., Kasanen, K., \& Kärkkäinen, R. (2002). Parents' explanations of their child's performance in mathematics and reading: A replication and extension of Yee and Eccles. Sex Roles, 46(3-4), 121-128. https://doi.org/10.1023/A:1016573627828

Rytkönen, K., Aunola, K., \& Nurmi, J. E. (2005). Parents' causal attributions concerning their children's school achievement: A longitudinal study. Merrill-Palmer Quarterly, 51(4), 494-522.

Sabancı, A. (2009). Views of primary school administrators, teachers and parents on parent involvement in Turkey. Egitim Arastirmalari - Eurasian Journal of Educational Research, 36, 245-246.

Şad, S. N. (2012). Investigation of parental involvement tasks as predictors of primary students' Turkish, math, and science \& technology achievement. Egitim Arastirmalari - Eurasian Journal of Educational Research, 48, 135-154.

Şencan, H. (2005). Sosyal ve davranışsal ölçümlerde güvenilirlik ve geçerlilik. Ankara: Seçkin publishing

Tabachnick, B. G. \& Fidell, L. S. (2007). Using multivariate statistics (5th edition). Boston, MA: Pearson.

Tekin, A. K. (2016). Parental perceptions of life context variables for involvement in their young children's education. Education 3-13, 44(3), 353-366.

Tõeväli, P. K., \& Kikas, E. (2017). Relations among parental causal attributions and children's math performance and task persistence. Educational Psychology, 37(3), 332-345.

Vygotsky, L.S. (1978). Mind in Society. (Eds. M. Cole, V.Joh-Steiner, S. Scribner, E. Souberman). Massachusetts: Harvard University Press.

Weiner, B. (2010). The development of an attribution-based theory of motivation: A history of ideas. Educational Psychologist, 45(1), 28-36. https://doi.org/10.1080/00461520903433596 
Appendix.

Parental Attribution Scale (Turkish form)

\begin{tabular}{|c|c|c|}
\hline Faktör & $\begin{array}{l}\text { Madde } \\
\text { no }\end{array}$ & Ifade \\
\hline \multirow[t]{3}{*}{ Başarı Şans } & 1 & $\begin{array}{l}\text { Çocuğum bir çalışma kağıdını iyi bir biçimde tamamlarsa, bu büyük } \\
\text { olasılıkla şanslı olduğu içindir. }\end{array}$ \\
\hline & 2 & $\begin{array}{l}\text { Çocuğum sınavlarda başarılı olursa, bu büyük olasılıkla şanslı olduğu } \\
\text { içindir. }\end{array}$ \\
\hline & 3 & Çocuğum okulda iyi notlar alırsa, bu büyük olasılıkla şanslı olduğu içindir. \\
\hline \multirow[t]{3}{*}{ Başarı Yetenek } & 4 & Çocuğum okulda bir ödül alırsa, bu büyük olasılıkla çok zeki olduğu içindir. \\
\hline & 5 & $\begin{array}{l}\text { Çocuğum ödevlerinden yüksek notlar aldığında, bunun nedeni büyük } \\
\text { olasılıkla çok parlak bir öğrenci olmasıdır. }\end{array}$ \\
\hline & 6 & $\begin{array}{l}\text { Çocuğum sınavlarda başarılı olursa, bu büyük olasılıkla çok parlak bir } \\
\text { öğrenci olduğu içindir }\end{array}$ \\
\hline \multirow[t]{3}{*}{ Başarı Çaba } & 7 & $\begin{array}{l}\text { Çocuğum okulun Matematik sınavında birinci olduğunda, bu büyük } \\
\text { olasılıkla çok çalıştığı içindir. }\end{array}$ \\
\hline & 8 & Çocuğumun okul notları iyi olursa, bu büyük olasılıkla çok çalıştığı içindir. \\
\hline & 9 & Çocuğum okulda bir ödül alırsa, bu büyük olasılıkla çok çalıştığı içindir. \\
\hline \multirow[t]{3}{*}{ Başarı Strateji } & 10 & $\begin{array}{l}\text { Çocuğum ödevleri için yüksek notlar aldığında, bu büyük olasılıkla etkili } \\
\text { çalışma yöntemleri olduğu içindir. }\end{array}$ \\
\hline & 11 & $\begin{array}{l}\text { Çocuğum okulun Matematik sınavında başarılı olduğunda, bunun nedeni } \\
\text { büyük olasılıkla bu dersle ilgili etkili çalışma yöntemlerini bilmesidir. }\end{array}$ \\
\hline & 12 & $\begin{array}{l}\text { Çocuğum ödevlerinden yüksek notlar aldığında, bu büyük olasılıkla } \\
\text { bununla ilgili kullanışlı yöntemleri olduğu içindir. }\end{array}$ \\
\hline \multirow[t]{3}{*}{ Başarısızlık Şanssızlık } & 13 & $\begin{array}{l}\text { Çocuğum okulda bir ödül alamazsa, bu büyük olasılıkla şanslı olmadığı } \\
\text { içindir }\end{array}$ \\
\hline & 14 & $\begin{array}{l}\text { Çocuğum ödevlerinden zayıf notlar aldığında, bu büyük olasılıkla şanslı } \\
\text { olmadığı içindir }\end{array}$ \\
\hline & 15 & $\begin{array}{l}\text { Çocuğum okulun Matematik sınavında sonuncu olduğunda, bunun nedeni } \\
\text { büyük olasılıkla şanslı olmamasıdır. }\end{array}$ \\
\hline \multirow[t]{3}{*}{ Başarısızlık Yetenek } & 16 & $\begin{array}{l}\text { Çocuğum bir çalışma kağıdının sadece yarısını tamamlarsa, bu büyük } \\
\text { olasılıkla bu konuda iyi olmadığı içindir. }\end{array}$ \\
\hline & 17 & $\begin{array}{l}\text { Çocuğum okulda zayıf notlar aldığında, bu durumun nedeni büyük } \\
\text { olasılıkla pek parlak bir öğrenci olmamasıdır. }\end{array}$ \\
\hline & 18 & $\begin{array}{l}\text { Çocuğum okuldaki Matematik sınavında kötü not aldığında, bu büyük } \\
\text { olasılıkla bu konuda iyi olmadığı içindir. }\end{array}$ \\
\hline \multirow[t]{3}{*}{ Başarısızlık Çaba } & 19 & $\begin{array}{l}\text { Çocuğum ödevlerinden zayıf notlar aldığında, bu büyük olasılıkla çok } \\
\text { çalışmadığı içindir. }\end{array}$ \\
\hline & 20 & $\begin{array}{l}\text { Çocuğum çalışma kağıtlarının sadece yarısını tamamlarsa, bu büyük } \\
\text { olasılıkla yeterince çok çalışmadığı içindir. }\end{array}$ \\
\hline & 21 & $\begin{array}{l}\text { Çocuğumun okul notları zayıf olursa, bu büyük olasılıkla yeterince } \\
\text { çalışmadığı içindir. }\end{array}$ \\
\hline \multirow[t]{3}{*}{ Başarısızlık Strateji } & 22 & $\begin{array}{l}\text { Çocuğum okulda bir ödül almadıysa, bu büyük olasılıkla bununla ilgili } \\
\text { kullanışlı yöntemleri olmadığı içindir. }\end{array}$ \\
\hline & 23 & $\begin{array}{l}\text { Çocuğum çalışma kağıtlarının sadece yarısını tamamlarsa, bu büyük } \\
\text { olasılıkla onunla ilgili etkili çalışma yöntemlerini bilmediği içindir. }\end{array}$ \\
\hline & 24 & $\begin{array}{l}\text { Çocuğumun okul notları zayıf geldiğinde, bunun nedeni büyük olasılıkla işe } \\
\text { yarar ders çalışma yöntemlerini bilmemesidir. }\end{array}$ \\
\hline
\end{tabular}

